\title{
The contents of the potentially harmful elements in the arable soils of southern Poland, with the assessment of ecological and health risks: a case study
}

\author{
Agnieszka Gruszecka-Kosowska (i) - Agnieszka Baran (D) Magdalena Wdowin (1) \\ Katarzyna Mazur-Kajta (D) Tomasz Czech
}

Received: 30 March 2019/Accepted: 3 July 2019/Published online: 19 July 2019

(C) The Author(s) 2019

\begin{abstract}
Agricultural soil samples were collected from the areas where edible plants had been cultivated in southern Poland. The PHE content decreased in proportion to the median value specified in brackets (mg/kg d.m.) as follows: $\mathrm{Zn} \mathrm{(192)}>\mathrm{Pb}(47.1)>\mathrm{Cr}$ $(19.6)>\mathrm{Cu} \quad(18.8)>\mathrm{Ni} \quad(9.91)>\mathrm{As} \quad(5.73)>\mathrm{Co}$ $(4.63)>\mathrm{Sb} \quad(0.85)>\mathrm{Tl} \quad(0.04)>\mathrm{Cd} \quad(0.03)>\mathrm{Hg}$ $(0.001)>\mathrm{Se} \quad(<\mathrm{LOQ})$. No PHE concentrations exceeded the permissible levels defined in the Polish law. The PHE solubility (extracted with $\mathrm{CaCl}_{2}$ ) in the total concentration ranged in the following order: $\mathrm{Fe}$ $(3.3 \%)>\mathrm{Cd} \quad(2.50 \%)>\mathrm{Ni} \quad(0.75 \%)>\mathrm{Zn}$ $(0.48 \%)>\mathrm{Cu}(0.19 \%)>\mathrm{Pb}(0.10 \%)>\mathrm{Cr}(0.03 \%)$. The soil contamination indices revealed moderate contamination with $\mathrm{Zn}$, ranging from uncontaminated
\end{abstract}

Electronic supplementary material The online version of this article (https://doi.org/10.1007/s10653-019-00372-w) contains supplementary material, which is available to authorized users.

\section{A. Gruszecka-Kosowska ( $\square)$}

Department of Environmental Protection, Faculty of Geology, Geophysics, and Environmental Protection, AGH University of Science and Technology, al.

Mickiewicza 30, 30-059 Kraków, Poland

e-mail: agnieszka.gruszecka@agh.edu.pl

\section{A. Baran · T. Czech}

Department of Agricultural and Environmental

Chemistry, Faculty of Agriculture and Economics,

University of Agriculture in Krakow, al. Mickiewicza 21,

31-120 Kraków, Poland to moderately contaminated with $\mathrm{Pb}$, and, practically, no contamination with other PHEs was identified. The ecological risk indices revealed that soils ranged from uncontaminated to slightly contaminated with $\mathrm{Zn}, \mathrm{Pb}$, $\mathrm{As}, \mathrm{Cu}$, and $\mathrm{Ni}$. The PCA indicated natural sources of origin of $\mathrm{Co}, \mathrm{Cu}, \mathrm{Hg}, \mathrm{Sb}, \mathrm{Zn}, \mathrm{Cr}$, and $\mathrm{Pb}$, as well as anthropogenic sources of origin of $\mathrm{Cd}, \mathrm{Ni}, \mathrm{As}$, and $\mathrm{Tl}$. The human health risk assessment (HHRA) for adults and children decreased in the following order of exposure pathways: ingestion $>$ dermal contact $>$ inhalation of soil particles. The total carcinogenic risk values for both adults and children were at the acceptable level under residential (1.62E-05 and $6.39 \mathrm{E}-05)$ and recreational scenario $(5.41 \mathrm{E}-06$ and $2.46 \mathrm{E}-05)$, respectively, as well as for adults in agricultural scenario (1.45E-05). The total noncarcinogenic risk values for both adults and children under residential scenario (1.63E-01 and 4.55E-01, respectively), under recreational scenario $(2.88 \mathrm{E}-01$ and $6.69 \mathrm{E}-01$, respectively) and for adults

\section{Wdowin}

Mineral and Energy Economy Research Institute, Polish Academy of Sciences, ul. J. Wybickiego 7A,

31-261 Kraków, Poland

K. Mazur-Kajta

Department of International Economic Relations, Faculty of Economics and Management, Opole University of Technology, ul. Prószkowska 76, 45-758 Opole, Poland 
(1.03E-01) under agricultural scenario indicated that adverse health effects were not likely to be observed. Investigated soils were fully suitable for edible plant cultivation.

Keywords Agricultural soils · Trace elements · Contamination factors · Ecological risk · Human health risk assessment $\cdot$ Bioavailability

\section{Introduction}

Arable land is of special concern since, due to its special designation for food production, it needs to meet strictly defined requirements, in terms of contaminant content. Primarily, those contaminates can penetrate soil directly, as a result of either natural or anthropogenic activities, but also in the process of self-cleaning of other environmental components, especially air. When the environment becomes more and more polluted, it seems to be inevitable that the concentrations of adverse substances in the soils used for food production may also increase. Moreover, while the areas of arable land are often surrounded by those of intense industrial activity and/or agglomerations with intense traffic and household contaminants, taking care of the arable land quality becomes the matter of highest importance.

Metals and metalloids, often jointly called the 'heavy metals', belong to the most significant inorganic soil contaminants. Some of the PHEs (As, Cd, $\mathrm{Cr}, \mathrm{Co}, \mathrm{Ni}, \mathrm{Pb}$ ) are classified as possibly carcinogenic to humans (IARC 2012) by the International Agency for Research on Cancer (IARC). On the other hand, spectrum of potentially toxic effects of heavy metals is very wide, from fatigue and headache (Pratush et al. 2018) to a series of symptoms associated with cardiovascular, renal, blood, nervous, and bone diseases (Zhuang et al. 2009) to severe damage of such critical organs as kidneys or the nervous system (Wadhwa et al. 2015; Cabral-Pinto et al. 2018).

Agricultural soils are threatened by the PHE pollution due to rapidly expanding urban and industrial areas or the intensive use of fertilizers and agrochemicals for the crop protection purposes (Kelepertzis et al. 2015; Klimek-Kopyra et al. 2015; Šukalić et al. 2018). Recent research on agricultural soils revealed the accelerated accumulation of heavy metals and associated health risk, especially due to greenhouse agricultural cultivation (Wan et al. 2019) and the usage of fertilizers and fungicides (Huang et al. 2019). Moreover, high impact of PHEs contamination on soils via atmospheric deposition is mainly generated by coal combustion (Peng et al. 2019) that in Poland is very common. Exceedance of regulation limits concerning PHEs content was observed in soils that are adjacent to megalopolises, large motorways and industrial enterprises (Barsova et al. 2019). The total PHE content is an important indicator of soil contamination, although this measure is not sufficient to assess any adverse effects that have actually occurred in the soil ecosystem (Baran et al. 2014, 2018; Kim et al. 2015; Jiang et al. 2019). In risk assessment, the data about the content of soluble or exchangeable trace element forms are useful since such elements display mobility from the solid phase to soil solution, once they become bioavailable (Jiang et al. 2019). PHEs do not accumulate in soils only, but they can also migrate to groundwater (Satapathy and Panda 2018) or penetrate higher links of the trophic chain (Dziubanek et al. 2015, 2017). What is more, PHEs are non-biodegradable and they can migrate from soil to groundwater causing further contamination. The speciation research of Wang et al. (2019) indicated that PHEs were very mobile and bioavailable in studied agricultural soils.

What is more and more popular is the trend of the so-called healthy eating (Kapetanaki et al. 2014; Banna et al. 2016; Rafacz 2019). That trend is mostly associated with the consumption of fresh food products, i.e., vegetables and fruit, grown by local farmers, without artificial fertilizers or plant protection chemicals. The local produce grown in such conditions is sold regionally, often brought straight from the farms to "fresh food markets", without washing with chemicals or packaging in plastic foil or containers. Also in Poland, such a trend becomes quite popular, which is especially visible in the southern regions of the country where industrial and post-industrial lands are mixed with farming regions. One can expect that the tendency will spread among the population. It is worth noting that arable lands constitute $73 \%$ of farmlands in Poland, and, together with forests, represent $90 \%$ of the country's surface area (GUS 2016). Chemical monitoring of arable soils is conducted by the National Environmental Monitoring System maintained by the IUNG Institute of Soil 
Science and Plant Cultivation in Puławy. The system produces 216 measurement-control profiles for arable soils in the whole country. The measurements have been taken every 5 years since 1995 (GIOŚ 2017).

Taking above under consideration, it could be assumed that PHEs concentrations in arable soils and consequently in edible plants will increase affecting human health. Thus, investigations of the arable soils of southern Poland, where edible plants (i.e., vegetables, fruit, and cereals) were simultaneously cultivated, were the goal of the study. The detailed objectives of the research were to determine (1) the mineralogical and geochemical characteristics of arable soils in southern Poland, (2) the total concentration of selected PHEs (As, Cd, Co, Cr, Cu, Hg, Ni, $\mathrm{Pb}, \mathrm{Sb}, \mathrm{Se}, \mathrm{Tl}$, and $\mathrm{Zn}$ ), with their bioavailability for plants, (3) the values of contamination indices for the total PHE content, and (4) the ecological and human health risk assessment values resulting from the presence of PHEs in arable soils.

\section{Materials and methods}

Study area, soil sampling, and sample preparation

The study areas were selected in southern Poland. Taking the administrative division of the country into consideration, 12 soil samples were collected in the Małopolskie Region, 4 in the Opolskie, 4 in the Ślackie, 6 in the Świętokrzyskie, and 4 in the Podkarpackie (Fig. 1). The soil sampling sites were located in the areas where edible plants (vegetables, fruit, and cereals) had been cultivated and subsequently sold to the residents of nearby cities on the local fruit and vegetable markets.

A total of 30 soil samples were collected from the depth of 0-25 cm each in 2015 and 2016, in accordance with the PN-ISO 10381-4:2007 Polish Standard protocol. The coordinates of the sample locations were recorded, using a portable Global Positioning System (GPS). About $1 \mathrm{~kg}$ of each soil sample was collected from a $1 \times 1 \mathrm{~m}$ square; each sample consisted of five subsamples (taken from the square corners and the diagonal intersection) of each sample grid. For each soil sample, duplicates were collected and analyzed in the same way as the basic samples. In the region of southern Poland where the investigations were conducted, soils were classified as cambisols, podzols, and luvisols according to World Reference Base for Soil Resources (IUSS Working Group WRB 2015). The soil samples were air-dried at room temperature $\left(25^{\circ} \mathrm{C}\right)$ and homogenized, with mass reduction by the ring and cone method. Then, the soil samples were passed through a 2-mm sieve to remove plant parts and gravel material before further analysis.

\section{Sample analysis}

Active $\left(\mathrm{pH}_{\mathrm{H} 2 \mathrm{O}}\right)$ and potential $\left(\mathrm{pH}_{\mathrm{KCl}}\right) \mathrm{pH}$ values were determined in duplicate soil samples using $5 \mathrm{~g}$ of soil sample and $25 \mathrm{~cm}^{3}$ of deionized water and $1 \mathrm{M} \mathrm{KCl}$, respectively (PN-ISO 10390:1997 protocol). The organic carbon $\left(C_{\text {org }}\right)$ content was determined by the Tiurin method (PN-ISO 14235:2003). Approximately $0.2 \mathrm{~g}$ of soil was weighed into $100 \mathrm{~cm}^{3}$ conical flasks, $10 \mathrm{~cm}^{3}$ of potassium dichromate in sulfuric acid (VI) at a concentration of $0.06 \mathrm{~mol} / \mathrm{dm}^{-3}$ and about $0.2 \mathrm{~g}$ of $\mathrm{HgSO}_{4}$ were added. Analysis of organic carbon content was performed in each soil sample in duplicate. The prepared sample in conical flasks with a glass funnel as a reflux condenser was heated on a hot plate for $2 \mathrm{~h}$, and after cooling, three drops of phenolphthalein were added. The solution thus prepared was titrated with Mohr's salt to change the color from orange to green to dark red. The organic matter (OM) content was determined gravimetrically on duplicate $5 \mathrm{~g}$ oven-dried samples, in a furnace, kept at $450{ }^{\circ} \mathrm{C}$ for $16 \mathrm{~h}$ (ISO 10694:1995).

$\mathrm{X}$-ray diffraction (XRD) patterns were recorded for powdered soil samples, with the use of a Rigaku MiniFlex diffractometer $(\mathrm{CuK} \alpha$ radiation), in the range of $1^{\circ}-14^{\circ} 2 \theta$, with the $0.05^{\circ} 2 \theta$ step. The values of interplanar distances, obtained from the X-ray images (in angstroms $=0.1 \mathrm{~nm}$ ), were used to identify the mineral phases that were part of the samples being studied. For the diffraction data processing, a ClayLAB, ver. 1.0, was used. The identification of mineral phases was carried out, based on a PCPDFWIN, ver. 1.30, formalized by JCPDS-ICDD.

A FEI Quanta 200 FEG scanning electron microscope (SEM), equipped with an EDS EDAX microarea analysis system, as well as a backscattered electron detector (YAG BSE), was also used in the research. Samples were sprayed with carbon before observation.

Thermal analysis (DTA/TG) was performed, using an STA 449 F3 Jupiter Netzsch apparatus, coupled 


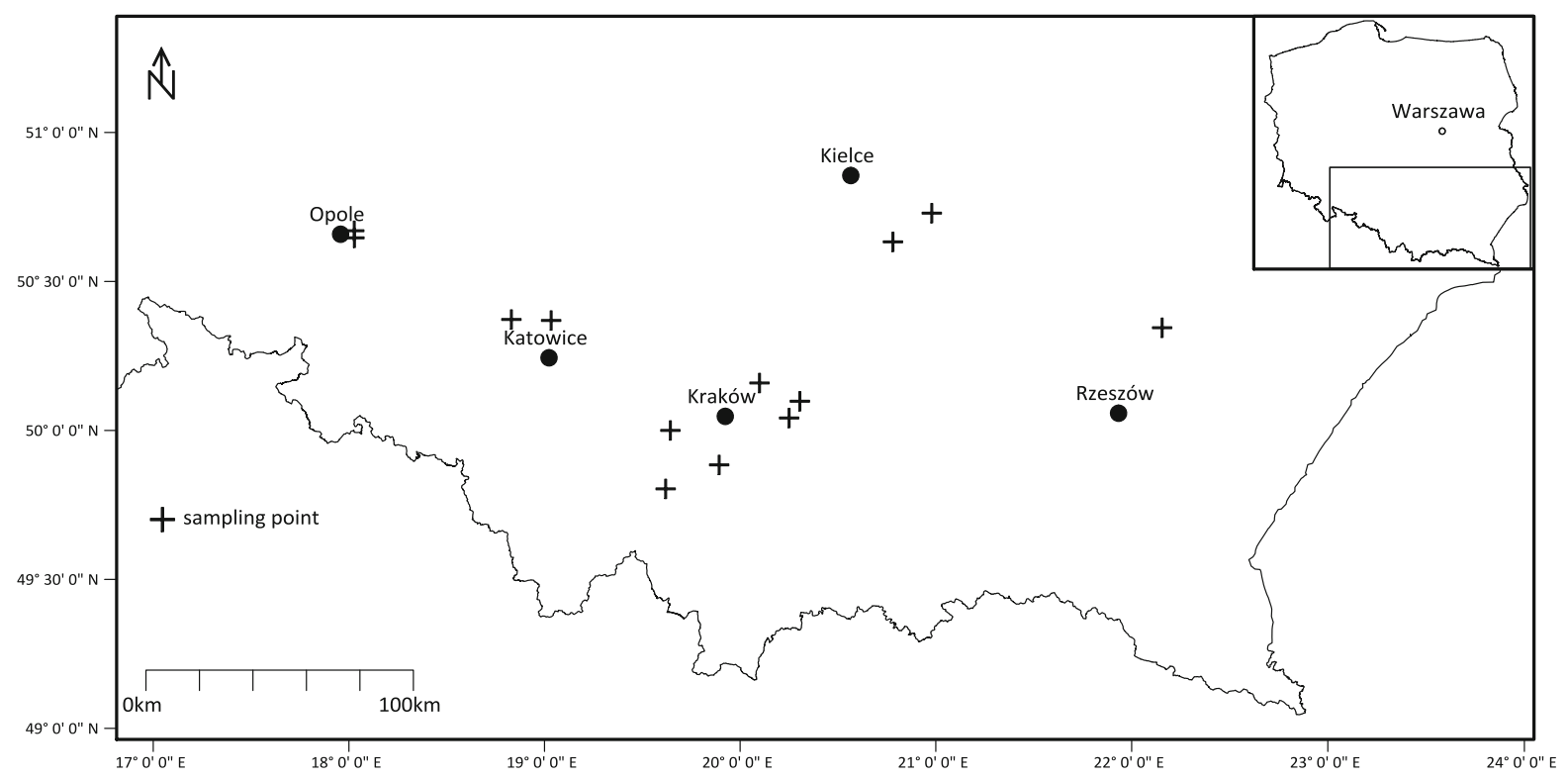

Fig. 1 Agricultural soil sampling site locations in southern Poland

with a quadrupole mass spectrometer, QMS 403C Aeolos, and an FTIR Bruker spectrometer.

The total PHE concentrations (As, $\mathrm{Cd}, \mathrm{Co}, \mathrm{Cr}, \mathrm{Cu}$, $\mathrm{Hg}, \mathrm{Ni}, \mathrm{Pb}, \mathrm{Sb}, \mathrm{Se}, \mathrm{Tl}$, and $\mathrm{Zn}$ ), as well as those of $\mathrm{Al}$ and $\mathrm{Fe}$ extracted in $3 \mathrm{~g}$ of soil samples with $28 \mathrm{~cm}^{3}$ of aqua regia $\left(\mathrm{HNO}_{3}\right.$ and $\mathrm{HCl}$ at 3:1 v/v) after mineralization in $105{ }^{\circ} \mathrm{C}$ for $2 \mathrm{~h}$, were determined by inductively coupled plasma mass spectrometry ICPMS (ELAN 6100; PerkinElmer, Waltham, MA, USA) according to the USEPA 6020B protocol (USEPA 1998 ) and the ISO protocol (PN-EN ISO 17294-2:2006).

The bioavailable forms of PHEs were extracted, $2 \mathrm{~g}$ of each soil sample, with $20 \mathrm{~cm}^{3}$ of $0.01 \mathrm{~mol} \mathrm{CaCl}_{2} /$ $\mathrm{dm}^{3}$ (Rauret 1998; Pueyo et al. 2004; Wieczorek et al. 2018) and shaken for $2 \mathrm{~h}$. After extraction, the samples were centrifuged at $3000 \mathrm{rpm}$ for $10 \mathrm{~min}$. The supernatants were separated from the precipitates through a filter. The contents of the bioavailable forms of PHEs were determined, using the ICP-OES (inductively coupled plasma optical emission spectroscopy) method, with an Optima 7300 DV (PerkinElmer).

Quality control

Soil analyses were performed, with the observance of the certified standard analytical quality control procedure (PN-EN ISO 17294-1:2007). To achieve impartial and unequivocal ICP-MS results, the elements were also measured, using ICP-OES inductively coupled plasma optical emission spectroscopy (OPTIMA 7300DV; PerkinElmer, Waltham, MA, USA), in accordance with the USEPA 6020B protocol (USEPA 1998) and the ISO protocol (PN-EN ISO 11885:2009). Certified reference material (CRM) (soil $\left.\mathrm{ERM}^{\circledR}-\mathrm{CC} 141\right)$ was analyzed at the same time. The recovery from the CRM soil was between $81 \%$ and $112 \%$ for the majority of the analyzed PHEs, except for As, Co, Cr, Ni. Reagent blanks and duplicates of each three samples were used to ensure quality assurance and quality control. All the reagents used in the laboratory analysis were analytically pure. The results of the samples were within the allowable error change values. Analytical bias was statistically insignificant $(p=0.05)$. The accuracy of the ICP-MS and ICP-OES systems was satisfactory and verified by six different solution injections. As an internal standard, Rh was used. For the ICP-MS analysis to minimize the impact of interferences, the element correction equations were used for each element.

The limit of quantification (LOQ) values of the investigated PHEs were as follows: $\mathrm{Al}<0.005 \mathrm{mg} /$ $\mathrm{dm}^{3}, \quad$ As $<0.001 \mathrm{mg} / \mathrm{dm}^{3}, \quad \mathrm{Cd}<0.003 \mathrm{mg} / \mathrm{dm}^{3}$, Co $<0.0002 \mathrm{mg} / \mathrm{dm}^{3}, \quad \mathrm{Cr}<0.005 \mathrm{mg} / \mathrm{dm}^{3}, \quad \mathrm{Cu}<$ $0.001 \mathrm{mg} / \mathrm{dm}^{3}, \quad \mathrm{Fe}<0.02 \mathrm{mg} / \mathrm{dm}^{3}, \quad \mathrm{Hg}<0.0001$ $\mathrm{mg} / \mathrm{dm}^{3}, \mathrm{Ni}<0.001 \mathrm{mg} / \mathrm{dm}^{3}, \mathrm{~Pb}<0.0001 \mathrm{mg} / \mathrm{dm}^{3}$, 
$\mathrm{Sb}<0.0002 \mathrm{mg} / \mathrm{dm}^{3} \quad \mathrm{Se}<0.01 \mathrm{mg} / \mathrm{dm}^{3}, \quad \mathrm{Tl}<$ $0.0001 \mathrm{mg} / \mathrm{dm}^{3}$, and $\mathrm{Zn}<0.001 \mathrm{mg} / \mathrm{dm}^{3}$.

Statistical analysis

The statistical analysis involved the determination of mean, median, standard deviation, minimum, maximum, and coefficient of variation $(\mathrm{CV} \%)$. The relationships between the parameters in soil samples were assessed, using the Pearson correlation coefficients and PCA. Statistical analyses were performed, using the Microsoft Excel 2007 spreadsheet and the Statistica 12 package.

Soil quality and contamination indices

In order to indicate a potential contamination of analyzed agricultural soils by PHEs under investigation, the permissible levels of metals and metalloids were used (Regulation of the Polish Minister of Environment on how to conduct pollution assessment the surface of the earth of 1 September 2016 (RMŚ 2016). Since not all the elements were included in the above-mentioned Polish Regulation, the Canadian soil quality guidelines for the protection of environmental and human health were also applied (CCME 2007). Furthermore, although the total concentration of metals and metalloids is still the most popular chemical indicator, contamination indices were also calculated as the first step of determining a potential grade of soil contamination. The pollution indices, based on the total PHEs concentration, were divided into two groups: individual and complex. The individual pollution indices determine the soil contamination separately for each element. The following single soil contamination indices were selected for our investigations: geoaccumulation index $\left(I_{\text {geo }}\right)$, enrichment factor (EF), contamination factor $(\mathrm{CF})$, single pollution index $(\mathrm{PI})$, threshold pollution index $\left(\mathrm{PI}_{\mathrm{T}}\right)$, and potential contamination index (PCI). However, while PHEs occur in the environment as mixtures, complex contamination indices determining the impact of many pollutants seem to be more adequate. The following complex soil contamination indices were chosen for the investigations: contamination degree $\left(\mathrm{C}_{\mathrm{deg}}\right)$, modified contamination degree $\left(\mathrm{mC}_{\mathrm{deg}}\right)$, sum of pollution index $\left(\mathrm{PI}_{\text {sum }}\right)$, sum of threshold pollution index $\left(\mathrm{PI}_{\text {Tsum }}\right)$, average pollution index $\left(\mathrm{PI}_{\mathrm{Avg}}\right)$, average pollution threshold index
$\left(\mathrm{PI}_{\mathrm{TAvg}}\right)$, pollution load index (PLI), and improved Nemerow pollution index $\left(\mathrm{PI}_{\mathrm{N}}\right)$. A brief description of the soil contamination indices, used in this study, is given in ESM_1. The local geochemical background $\mathrm{B}_{n}$ values (Kabata-Pendias 2011), needed for calculations, were used in the $I_{\text {geo }}$ index, as well as those from Rudnick and Gao (2014), determining concentration in the upper continental crust as preindustrial values. $\mathrm{Fe}$ as a heavy metal, characterized by a low variability of occurrence, was chosen for the calculations of the EF factor (Kowalska et al. 2018). Calculations were performed twice; first, the $\mathrm{B}_{\mathrm{Fe}}$ concentration was chosen from crust soils (Kabata-Pendias 2011), and then as a regional geochemical background for loamy soils in Poland (Kabata-Pendias and Pendias 1999; Kabata-Pendias 2011). In the CF factor, significant preindustrial concentration values of PHEs were taken from the upper continental crust, as reference values, in accordance with Rudnick and Gao (2014), while in the single PI index, the background values for the PHEs data from Kabata-Pendias and Pendias (1999) and Kabata-Pendias (2011) were used. In the case of the single PI index and the potential contamination PCI index, the local values of geochemical background were used (Kabata-Pendias 2011). In the case of the single $\mathrm{PI}_{\mathrm{T}}$ index, the Polish soil environment quality standards were used (RMŚ 2016). Whenever the PHEs under examination were missing in the Polish Regulation, the values from the Canadian soil quality guidelines for the protection of environmental and human health (CCME 2007) were applied.

\section{Ecological risk indices}

To determine a more realistic impact of elements on living organisms, several ecological risk indices were developed. They were based on the threshold effect concentrations, below which harmful effects were unlikely to be observed (TECs) and on probable effects of the concentrations (PECs), above which harmful effects were likely to be observed (MacDonald et al. 2000). Thus, in the second step of determining soil quality, some sediment quality indices were also used for soils (Qui 2010; Inengite et al. 2015; Weissmanová and Pavlovský 2017). The following single ecological risk indices were selected for the investigations: potential ecological risk coefficient (Er), hazard quotient (HQ), and modified hazard quotient (mHQ); the complex ecological risk indices 
were the following: potential ecological risk index (RI), hazard index (HI), mean probable effects level quotient (mPELq), mean effect range median quotient (mERMq), ecological contamination index (ECI), and contamination severity index (CSI). A brief description of the ecological risk indices, used in the study, is given in ESM_2. The above values of individual PHE permissible levels, specified in RMŚ (2016) and CCME (2007), were used as standard.

\section{Human health risk assessment}

The methodology used for human health risk assessment (HHRA) was based on the guidelines provided by the US Environmental Protection Agency (USEPA 1989). In the research, three site-specific exposure scenarios were investigated. The first exposure scenario was assumed to be agricultural: soil cultivation by adults was investigated. The second exposure scenario was assumed to be residential and the third one recreational. Within the second and the third exposure scenarios, the populations of both adults and children were investigated. Moreover, under each exposure scenario, three exposure routes were investigated: inhalation of resuspended soil particles, accidental soil ingestion, and dermal contact with soil. Thus, average daily doses (ADD) for ingestion exposure and dermal exposure, as well as exposure concentrations (EC) for the inhalation route, were calculated according to Eqs. (1)-(3) (USEPA 2001, 2004, 2009; Izquierdo et al. 2015; Wcisło et al. 2016), respectively:

$$
\begin{aligned}
& \mathrm{ADD}_{\text {soil ingestion }}=\left(C_{\text {soil }} \times \mathrm{CF} \times \mathrm{IR}_{\text {ing }} \times \mathrm{FI} \times \mathrm{EF}\right. \\
& \times \mathrm{ED} \times \mathrm{RBA}) /(\mathrm{BW} \times \mathrm{AT})
\end{aligned}
$$

$$
\begin{gathered}
\mathrm{ADD}_{\text {dermal contact }}=\left(C_{\text {soil }} \times \mathrm{CF} \times \mathrm{AF} \times \mathrm{ABS}_{\mathrm{d}}\right. \\
\times \mathrm{EF} \times \mathrm{ED} \times \mathrm{EV} \times \mathrm{SA}) /(\mathrm{BW} \times \mathrm{AT}) \\
\mathrm{EC}=\left(C_{\text {soil }} \times \mathrm{ET} \times \mathrm{EF} \times \mathrm{ED}\right) /(\mathrm{PEF} \times \mathrm{AT})
\end{gathered}
$$

where ADD is the average daily dose ( $\mathrm{mg} / \mathrm{kg}$ day); EC, exposure concentration $\left(\mathrm{mg} / \mathrm{m}^{3}\right) ; C_{\text {soil }}$, mean concentration of analyzed PHE in soil samples $(\mathrm{mg} /$ $\mathrm{kg})$; CF, unit conversion factor $\left(10^{-6} \mathrm{~kg} / \mathrm{mg}\right)$; $\mathrm{IR}_{\mathrm{ing}}$, soil ingestion rate $(\mathrm{mg} / \mathrm{kg})$; FI, fraction ingested from contaminated source (unitless); EF, exposure frequency (days/year); ED, exposure duration (years);
RBA, relative bioavailability factor (unitless); BW, body weight $(\mathrm{kg})$; $\mathrm{AF}$, adherence factor of soil to skin (mg/ $\mathrm{cm}^{2}$-event); $\mathrm{ABS}_{\mathrm{d}}$, dermal absorption factor (unitless); EV, event frequency (events/day); SA, skin surface area available for contact $\left(\mathrm{cm}^{2}\right)$; ET, exposure time for receptor (h/day); PEF, soil-to-air particulate emission factor $\left(\mathrm{m}^{3} / \mathrm{kg}\right)$; AT, averaging time $(\mathrm{ED} \times$ 365 days for non-carcinogens and $70 \times 365$ days for carcinogens; in days for ingestion and dermal contact; in hours for inhalational exposure). The exposure parameters, used for the HHRA calculations under concerned site-specific scenarios, are given in Table 1.

To determine the non-carcinogenic and carcinogenic risks arising from the content of PHEs analyzed in soils, the HQ and CR values were calculated, respectively. The values of the hazard indices (HQ) in oral and dermal exposure pathways were calculated, using Eq. (4), and those regarding the inhalational route, using Eq. (5). The values of the carcinogenic risks (CR) for oral and dermal exposure pathways were calculated according to Eq. (6) and those regarding the inhalational exposure, using Eq. (7) (USEPA 1989, 2009; Wcisło et al. 2016):

$$
\begin{aligned}
& \mathrm{HQ}=\mathrm{ADD} / \mathrm{RfD}_{\mathrm{o}} \\
& \mathrm{HQ}=\mathrm{EC} / \mathrm{RfC} \\
& \mathrm{CR}=\mathrm{ADD} \times \mathrm{SF}_{\mathrm{o}} \\
& \mathrm{CR}=\mathrm{EC} \times \mathrm{IUR}
\end{aligned}
$$

where HQ is the hazard quotient (unitless); CR, carcinogenic risk (unitless); ADD, average daily dose (mg/kg day); EC, exposure concentration $\left(\mathrm{mg} / \mathrm{m}^{3}\right)$; $\mathrm{RfD}_{\mathrm{o}}$, oral reference dose ( $\mathrm{mg} / \mathrm{kg}$ day); RfC, reference concentration $\left(\mathrm{mg} / \mathrm{m}^{3}\right) ; \mathrm{SF}_{\mathrm{o}}$, oral slope factor; IUR, inhalation unit risk $\left(\mathrm{mg} / \mathrm{m}^{3}\right)$. The reference doses $\left(\mathrm{RfD}_{\mathrm{d}}\right)$ and slope factor values $\left(\mathrm{SF}_{\mathrm{d}}\right)$ for dermal contact were calculated according to Eqs. (8) and (9), respectively (Wcisło et al. 2016):

$\mathrm{RfD}_{\mathrm{d}}=\mathrm{RfD}_{\mathrm{o}} / \mathrm{GIABS}$

$\mathrm{SF}_{\mathrm{d}}=\mathrm{SF}_{\mathrm{o}} \times \mathrm{GIABS}$

where GIABS is the fraction of contaminant absorbed in the gastrointestinal tract (unitless).

The total non-carcinogenic risk of PHEs was determined by the hazard index $\left(\mathrm{HI}_{t}\right)$ values, 
Table 1 Exposure parameters used for the HHRA calculations in the study

\begin{tabular}{|c|c|c|c|c|c|c|}
\hline \multirow[t]{2}{*}{ Exposure parameters } & \multicolumn{2}{|l|}{ Residential } & \multicolumn{2}{|l|}{ Recreational } & \multirow{2}{*}{$\begin{array}{l}\text { Agricultural } \\
\text { Adult }\end{array}$} & \multirow[t]{2}{*}{ References } \\
\hline & Adult & Child & Adult & Child & & \\
\hline $\begin{array}{l}\mathrm{IR}_{\text {ing }} \text { - } \text { soil ingestion rate }(\mathrm{mg} / \\
\mathrm{kg})\end{array}$ & 100 & 200 & 100 & 200 & 100 & USEPA (2011) \\
\hline $\begin{array}{l}\mathrm{IR}_{\text {inh }} \text {-inhalation rate for } \\
\text { receptor }\left(\mathrm{m}^{3} / \mathrm{h}\right)\end{array}$ & 0.83 & 0.31 & 0.83 & 0.31 & 0.83 & USEPA $(2002,2008)$ \\
\hline $\begin{array}{l}\mathrm{CF} \text { - unit conversion factor } \\
(\mathrm{kg} / \mathrm{mg})\end{array}$ & $10^{-6}$ & $10^{-6}$ & $10^{-6}$ & $10^{-6}$ & $10^{-6}$ & USEPA (2011) \\
\hline $\begin{array}{l}\text { FI-fraction ingested from } \\
\text { contaminated source } \\
\text { (unitless) }\end{array}$ & 1 & 1 & 1 & 1 & 1 & USEPA (2001) \\
\hline $\begin{array}{l}\text { ET_exposure time for } \\
\text { receptor (h/day) }\end{array}$ & 24 & 24 & 4 & 4 & 8 & Site specific \\
\hline ED—exposure duration (years) & 24 & 6 & 24 & 6 & 40 & $\begin{array}{l}\text { US EPA (2001) and Wcisło } \\
\text { et al. (2016) }\end{array}$ \\
\hline $\begin{array}{l}\text { EF-exposure frequency } \\
\text { (days/year) }\end{array}$ & 365 & 365 & $96^{\mathrm{a}}$ & $96^{\mathrm{a}}$ & $250^{\mathrm{b}}$ & $\begin{array}{l}\text { USEPA (2011); site specific; } \\
\text { Journal of Laws (1951) }\end{array}$ \\
\hline $\begin{array}{l}\text { EV_-event frequency } \\
\text { (events/day) }\end{array}$ & 1 & 1 & 1 & 1 & 1 & Site specific \\
\hline $\begin{array}{l}\mathrm{AF} \text { - adherence factor of soil } \\
\text { to skin }\left(\mathrm{mg} / \mathrm{cm}^{2} \text {-event }\right)\end{array}$ & 0.07 & 0.2 & 0.07 & 0.2 & 0.07 & USEPA (2011) \\
\hline $\begin{array}{l}\text { SA-skin surface area } \\
\text { available for contact }\left(\mathrm{cm}^{2}\right)\end{array}$ & 6032 & 2373 & 6032 & 2373 & 3527 & USEPA (2014) \\
\hline $\begin{array}{l}\mathrm{PEF} \text { —soil-to-air particulate } \\
\text { emission factor }\left(\mathrm{m}^{3} / \mathrm{kg}\right)\end{array}$ & $1.36 \times 10^{9}$ & $1.36 \times 10^{9}$ & $1.36 \times 10^{9}$ & $1.36 \times 10^{9}$ & $1.36 \times 10^{9}$ & USEPA (2002) \\
\hline BW—body weight (kg) & 70 & 15 & 70 & 15 & 70 & USEPA (2011) \\
\hline $\begin{array}{l}\text { AT—averaging time non- } \\
\text { carcinogens (days) }\end{array}$ & 8760 & 2190 & 8760 & 2190 & 14,600 & USEPA (2001) \\
\hline $\begin{array}{l}\text { AT—averaging time } \\
\text { carcinogens (days) }\end{array}$ & 25,550 & 25,550 & 25,550 & 25,550 & 25,550 & USEPA (2001) \\
\hline $\begin{array}{l}\text { AT-averaging time non- } \\
\text { carcinogens (hours) }\end{array}$ & 210,240 & 52,560 & 210,240 & 52,560 & 210,240 & USEPA (2009) \\
\hline $\begin{array}{l}\text { AT_-averaging time } \\
\text { carcinogens (hours) }\end{array}$ & 613,200 & 613,200 & 613,200 & 613,200 & 613,200 & USEPA (2009) \\
\hline
\end{tabular}

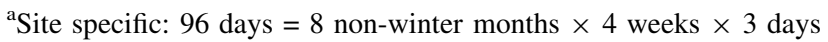

${ }^{\mathrm{b}}$ Site specific, based on the Polish Act on non-working days of 18 January 1951 (Journal of Laws 1951)

according to Eq. (10), and the total carcinogenic risks $\left(\mathrm{CR}_{t}\right)$ of analyzed PHEs according to Eq. (11):

$\mathrm{HI}_{t}=\mathrm{HQ}_{1}+\mathrm{HQ}_{2}+\cdots+\mathrm{HQ}_{i}$

$\mathrm{CR}_{t}=\mathrm{CR}_{1}+\mathrm{CR}_{2}+\cdots+\mathrm{CR}_{i}$

where $1-n$ were individual PHEs.

The values of toxicological parameters, used for the calculations of the site-specific HHRA, are given in Table 2.
The target risk value was set to be equal to 1 $(\mathrm{HQ}=1)$ for both non-carcinogenic risk, for each PHE investigated (individual HQ values), and the total non-carcinogenic risk, defined by $\mathrm{HI}_{\mathrm{t}}$ values. As to carcinogenic risk, the acceptable risk level was set to be equal to $1 \times 10^{-6}$ for an individual PHE and equal to $1 \times 10^{-4}$ for the sum of carcinogenic PHEs (USEPA 1989, 1991). 


\section{Results}

Physicochemical characterization of soils

The mean total concentrations of the PHEs, analyzed in the agricultural soils of southern Poland, the $\mathrm{pH}$ values, the contents of organic matter and organic carbon, and the content of the $<0.02 \mathrm{~mm}$ fraction are presented in Table 3. Soil $\mathrm{pH}$ was in the range of 4.8-7.2 for $\mathrm{pH}_{\mathrm{H} 2 \mathrm{O}}$ and 3.9-7.5 for $\mathrm{pH}_{\mathrm{KCl}}$; the median value of $\mathrm{pH}$ indicated that soils were from neutral to slightly acidic. Fraction $<0.02 \mathrm{~mm}$ was in the range of $7-50 \%$, with the mean value of $26 \%$ (GIOS 2017). The content of organic matter differed from 1.01 to $6.00 \%$, with the mean value of $2.73 \%$. The $C_{\text {org }}$ content varied from 5.95 to $34.8 \mathrm{~g} / \mathrm{kg}$, and the median value was equal to $15.2 \mathrm{~g} / \mathrm{kg}$. Based on the fraction $<0.02 \mathrm{~mm}$ content, the investigated soils were generally classified as loamy. The concentration of elements, characterized by a low variability of occurrence (As and $\mathrm{Fe}$ ), ranged from 0.25 to $1.16 \%$, with the mean concentration of $0.65 \%$ in the case of $\mathrm{Al}$ and in the range $0.34-3.23 \%$, with the mean content of
$0.98 \%$, in the case of Fe. Based on twelve investigated PHEs, the Se concentrations were $<$ LOQ in all the investigated samples. As to $\mathrm{Cd}, \mathrm{Hg}$, and $\mathrm{Tl}$, the minimum concentrations were $<$ LOQ and the maximum ones were equal to $3.53 \mathrm{mg} / \mathrm{kg} \mathrm{d} . \mathrm{m}$. for $\mathrm{Cd}$, $0.52 \mathrm{mg} / \mathrm{kg} \mathrm{d} . \mathrm{m}$. for $\mathrm{Hg}$, and $0.35 \mathrm{mg} / \mathrm{kg} \mathrm{d}$. $\mathrm{m}$. for $\mathrm{Tl}$. Their median concentrations were equal to $0.03 \mathrm{mg} /$ $\mathrm{kg}, 0.001 \mathrm{mg} / \mathrm{kg}$, and $0.04 \mathrm{mg} / \mathrm{kg}$, respectively. The other PHEs were ordered decreasingly as follows, with the median values (mg/kg d.m.) given in brackets: $\mathrm{Zn}$

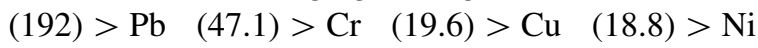
(9.91) $>$ As (5.73) $>\mathrm{Co}(4.63)>\mathrm{Sb}(0.85)$.

\section{Mineralogical characterization of soils}

The TG analysis (Fig. 2) showed loss in weight, in the proportion of only about $5 \%$, which suggested a low content of organic matter and a small amount of water in soil. The fastest loss was observed in the temperature range of $0-600{ }^{\circ} \mathrm{C}$. The DTA curve indicated two main endothermic reaction bands, the first one in the range of $100-200{ }^{\circ} \mathrm{C}$, associated with the removal of water, and the second one at $570{ }^{\circ} \mathrm{C}$, associated

Table 2 Toxicological parameters used for the HHRA calculations in the study

\begin{tabular}{|c|c|c|c|c|c|c|c|}
\hline Toxicological parameters & $\begin{array}{l}\mathrm{RfD}_{\mathrm{o}}^{\mathrm{a}} \\
\mathrm{mg} / \mathrm{kg} \text { day }\end{array}$ & $\begin{array}{l}\mathrm{SF}_{\mathrm{o}}^{\mathrm{a}} \\
(\mathrm{mg} / \mathrm{kg} \text { day })^{-1}\end{array}$ & $\begin{array}{l}\mathrm{RfC}^{\mathrm{a}} \\
\mathrm{mg} / \mathrm{m}^{3}\end{array}$ & $\begin{array}{l}\mathrm{IUR}^{\mathrm{a}} \\
\left(\mathrm{mg} / \mathrm{m}^{3}\right)^{-1}\end{array}$ & $\begin{array}{l}\mathrm{RBA}^{\mathrm{a}} \\
\text { unitless }\end{array}$ & $\begin{array}{l}\mathrm{ABS}_{\mathrm{d}}^{\mathrm{b}} \\
\text { unitless }\end{array}$ & $\begin{array}{l}\text { GIABS }^{\mathrm{c}} \\
\text { unitless }\end{array}$ \\
\hline As & $3.00 \mathrm{E}-04$ & $1.50 \mathrm{E}+00$ & $1.50 \mathrm{E}-05$ & $4.30 \mathrm{E}-06$ & 0.6 & 0.03 & 1 \\
\hline $\mathrm{Cd}$ & $1.00 \mathrm{E}-03$ & - & $1.00 \mathrm{E}-05$ & $1.80 \mathrm{E}-06$ & 1 & 0.01 & 0.025 \\
\hline Co & $3.00 \mathrm{E}-04$ & - & $6.00 \mathrm{E}-06$ & $9.00 \mathrm{E}-06$ & 1 & 0.01 & 1 \\
\hline $\mathrm{Cr}$ (III) & $1.50 \mathrm{E}+00$ & - & - & - & 1 & 0.01 & 0.013 \\
\hline $\mathrm{Cr}(\mathrm{VI})$ & $3.00 \mathrm{E}-03$ & $5.00 \mathrm{E}-01$ & $1.00 \mathrm{E}-04$ & $8.40 \mathrm{E}-05$ & 1 & 0.01 & 0.025 \\
\hline $\mathrm{Cu}$ & $4.00 \mathrm{E}-02$ & - & - & - & 1 & 0.01 & 1 \\
\hline $\mathrm{Hg}$ & $3.00 \mathrm{E}-04$ & - & $3.00 \mathrm{E}-04$ & - & 1 & 0.01 & 0.07 \\
\hline $\mathrm{Ni}$ & $2.00 \mathrm{E}-02$ & - & $9.00 \mathrm{E}-05$ & $2.60 \mathrm{E}-07$ & 1 & 0.01 & 0.04 \\
\hline $\mathrm{Pb}$ & $1.50 \mathrm{E}-03^{\mathrm{d}}$ & $8.50 \mathrm{E}-03$ & - & - & 1 & 0.01 & 1 \\
\hline $\mathrm{Sb}$ & $4.00 \mathrm{E}-04$ & - & - & - & 1 & 0.01 & 0.15 \\
\hline $\mathrm{Se}$ & $5.00 \mathrm{E}-03$ & - & $2.00 \mathrm{E}-02$ & - & 1 & 0.01 & 0.3 \\
\hline $\mathrm{Tl}$ & $1.00 \mathrm{E}-05$ & - & - & - & 1 & 0.01 & 1 \\
\hline $\mathrm{Zn}$ & $3.00 \mathrm{E}-01$ & - & - & - & 1 & 0.01 & 1 \\
\hline
\end{tabular}

$\mathrm{RfD}_{\mathrm{o}}$, oral reference dose; $\mathrm{SF}_{\mathrm{o}}$, oral slope factor; -, not available

${ }^{\mathrm{a}}$ USEPA (2019)

${ }^{\mathrm{b}}$ USEPA (2018)

${ }^{\mathrm{c}}$ USEPA (2004)

${ }^{\mathrm{d}}$ EFSA (2010) 
Table 3 Total PHE concentrations and the physicochemical parameters of the agricultural soils in southern Poland

\begin{tabular}{|c|c|c|c|c|c|c|c|c|c|}
\hline \multirow[t]{2}{*}{ Parameters } & \multirow[t]{2}{*}{ Units } & \multicolumn{4}{|c|}{ Soil $(n=30)$} & \multirow[t]{2}{*}{$\begin{array}{l}\text { Permissible concentration, } \\
\text { Polish guidelines (RMŚ } \\
\text { 2016) }\end{array}$} & \multicolumn{3}{|c|}{$\begin{array}{l}\text { Canadian Soil Quality Guidelines for the } \\
\text { Protection of Environment and Human } \\
\text { Health (CCME 2007) }\end{array}$} \\
\hline & & Min & Max & Mean & Median & & Agricultural & Residential & Commercial \\
\hline $\mathrm{pH}_{\mathrm{H} 2 \mathrm{O}}$ & - & 4.8 & 7.9 & 6.5 & 6.8 & - & - & - & - \\
\hline $\mathrm{pH}_{\mathrm{KCl}}$ & - & 3.9 & 7.5 & 6.0 & 6.3 & - & - & - & - \\
\hline $\begin{array}{r}\text { Organic } \\
\text { matter }\end{array}$ & $\%$ & 1.01 & 6.00 & 2.73 & 2.39 & - & - & - & - \\
\hline$C_{\text {org }}$ & $\mathrm{g} / \mathrm{kg}$ & 5.88 & 34.8 & 15.8 & 13.9 & - & - & - & - \\
\hline $\mathrm{Al}$ & $\%$ & 0.25 & 1.16 & 0.65 & 0.56 & - & - & - & - \\
\hline $\mathrm{Fe}$ & $\%$ & 0.34 & 3.23 & 0.98 & 0.85 & - & - & - & - \\
\hline As & $\mathrm{mg} /$ & 1.40 & 16.6 & 6.64 & 5.73 & 20 & 12 & 12 & 12 \\
\hline $\mathrm{Cd}$ & $\mathrm{kg}$ & $<\mathrm{LOQ}$ & 3.53 & 0.39 & 0.03 & 3 & 1.4 & 10 & 22 \\
\hline Co & & 1.44 & 12.3 & 4.92 & 4.63 & 30 & 40 & 50 & 300 \\
\hline $\mathrm{Cr}$ & & 2.08 & 35.4 & 18.8 & 19.6 & 300 & 64 & 64 & 87 \\
\hline $\mathrm{Cu}$ & & 5.23 & 110 & 26.6 & 18.8 & 150 & 63 & 63 & 91 \\
\hline $\mathrm{Hg}$ & & $<\mathrm{LOQ}$ & 0.52 & 0.05 & 0.001 & 4 & 6.6 & 6.6 & 24 \\
\hline $\mathrm{Ni}$ & & 1.06 & 27.1 & 11.5 & 9.91 & 150 & 45 & 45 & 89 \\
\hline $\mathrm{Pb}$ & & 14.2 & 263 & 63.8 & 47.1 & 250 & 70 & 140 & 260 \\
\hline $\mathrm{Sb}$ & & 0.03 & 3.07 & 1.23 & 0.95 & - & 20 & 20 & 40 \\
\hline $\mathrm{Se}$ & & $<\mathrm{LOQ}$ & $<\mathrm{LOQ}$ & $<\mathrm{LOQ}$ & $<\mathrm{LOQ}$ & - & 1 & 1 & 2.9 \\
\hline $\mathrm{Tl}$ & & $<\mathrm{LOQ}$ & 0.35 & 0.10 & 0.04 & - & 1 & 1 & 1 \\
\hline $\mathrm{Zn}$ & & 38.5 & 1224 & 283 & 192 & 500 & 250 & 250 & 410 \\
\hline
\end{tabular}

$<$ LOQ, below the limit of quantification; -, not applicable

RMŚ (2016) Regulation of the Polish Minister of Environment on how to conduct pollution assessment the surface of the earth of 1 Sept. 2016. OJ 2016. item 1395

CCME (2007) Canadian Council of Ministers of the Environment. 2007. Canadian soil quality guidelines for the protection of environmental and human health: Summary Tables. Updated September. 2007. In: Canadian environmental quality guidelines. 1999. Canadian Council of Ministers of the Environment. Winnipeg.

with the transition of quartz from a low-temperature quartz form (quartz- $\alpha$ ) to a high-temperature one (quartz- $\beta$ ). In addition, two important exothermic reaction bands were visible: the first one, in the range of $250-400{ }^{\circ} \mathrm{C}$, associated with the dehydration and thermal decomposition of humic substance in a mineralized residue, consisted mainly of clay minerals and oxides, as well as carbonates formed during the decomposition of organic matter (de Oliviera et al. 2009), and the second one, in the range of 900-1000 ${ }^{\circ} \mathrm{C}$, associated with the material decomposition and the formation of new mineral phases. The mineralogical XRD analysis (Fig. 3) revealed that the mineral composition of the analyzed soil samples was dominated by quartz. In addition, small amounts of feldspars, illite, montmorillonite, kaolinite, and goethite were visible. The samples differed only in the amount of individual components. Based on that, one might conclude that the clay minerals and organic matter, confirmed by the TGA analysis, were responsible for the presence of PHEs in soils. The morphology investigations and grain observations, using SEM-EDS, indicated that quartz with various crystal sizes was a dominant component (Fig. 4). Moreover, small aggregates of clay minerals were observed, together with feldspar crystals. Due to a very similar mineral composition of all the investigated soils, the highest concentrations of PHEs could be associated with anthropogenic activities rather than mineral composition. 


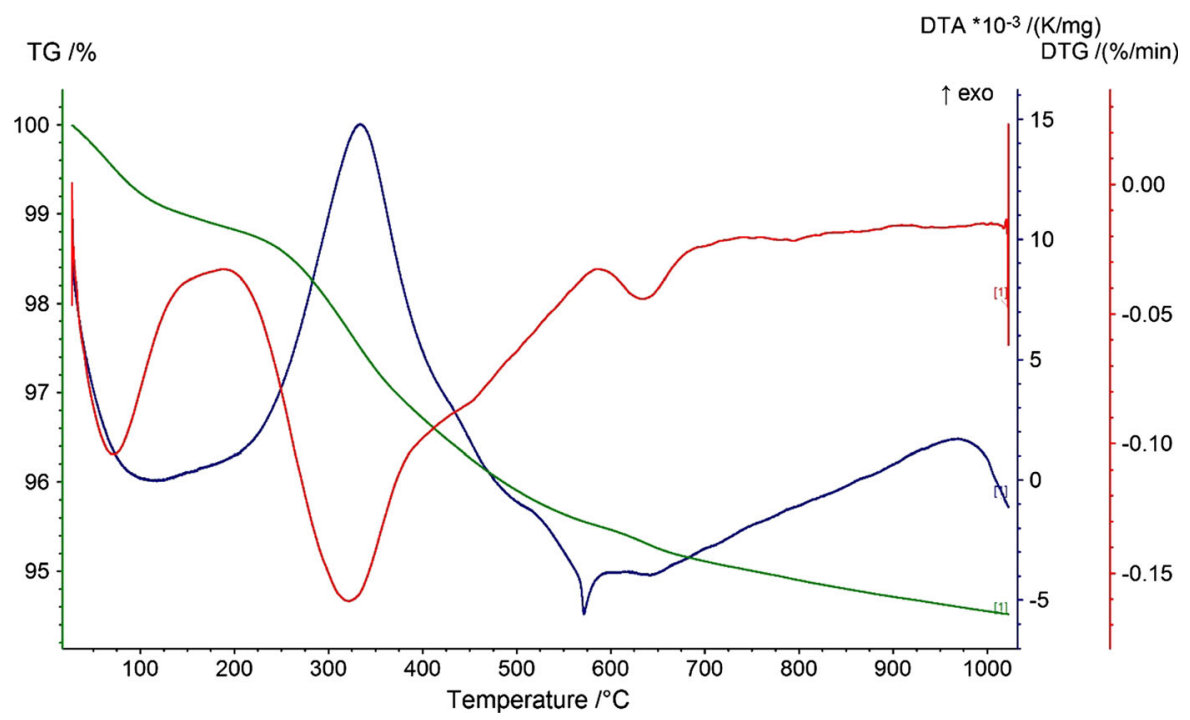

Fig. 2 TG analyses of the agricultural soils samples

Fig. 3 An example of the XRD diffraction pattern of the agricultural soil samples

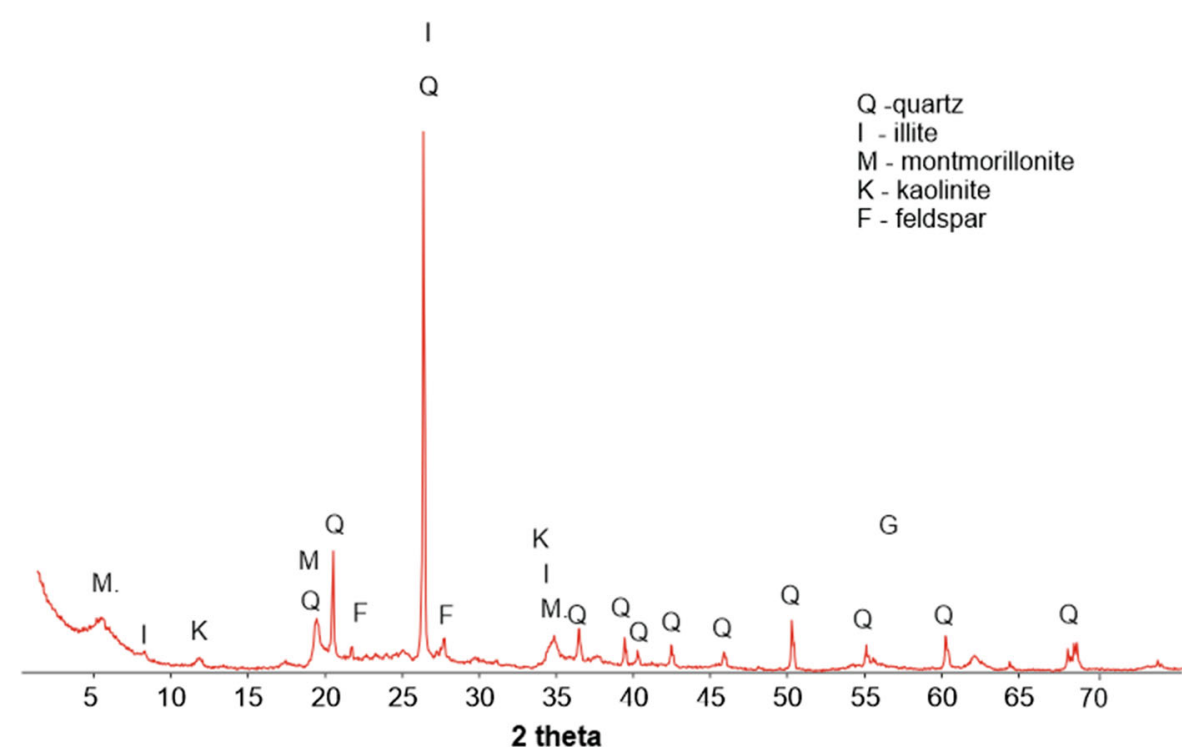

Soil quality standards

The mean concentrations of twelve PHEs analyzed were compared to the permissible concentrations of metals and metalloids, specified in RMŚ (2016) for Ground Type II-2, in reference to the content of the $<0.02 \mathrm{~mm}$ fraction and the $\mathrm{pH}_{\mathrm{KCl}}$ values (Table 3). Neither PHE concentration exceeded the permissible levels defined in RMŚ (2016). As to Sb, Se, and Tl, for which no permissible levels were determined in the Polish law, the values specified in the Canadian soil quality guidelines for the protection of environment and human health (CCME 2007) were adopted, and the guideline concentrations were not exceeded either. However, we need to mention that the Canadian soil guidelines show much lower permissible levels than the Polish ones. Since the Canadian guidelines were developed for the protection of environment and human health, the mean and median values of the other PHEs investigated in the soils of southern Poland were also compared to them. Similarly, none of the PHEs exceeded the guideline values; however, the $\mathrm{Zn}$ and $\mathrm{Pb}$ 


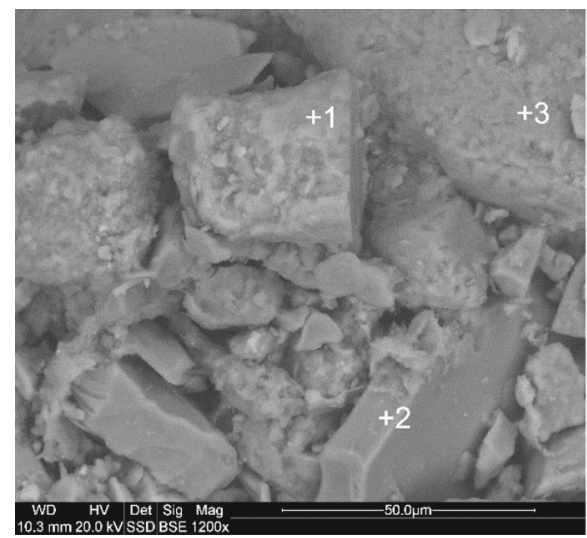

Left:

1 - feldspar, 2 - quartz, 3 - quartz

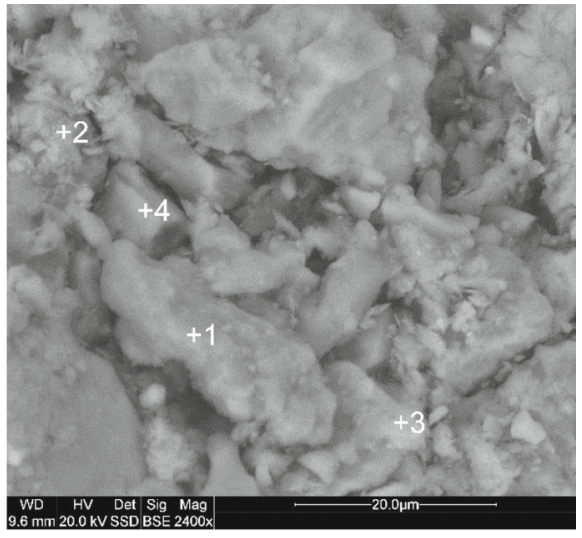

Right:

1 - feldspar, 2 - quartz, 3 and 4 - clay minerals

Fig. 4 SEM microphotographs of the agricultural soil samples, with EDS analysis in microareas

levels were exceeded depending on the fact whether the mean or median values were taken into consideration.

Assessment of the potential bioavailable forms of PHEs

The content of bioavailable forms of PHEs in soil samples varied, within a wide range, from $<$ LOQ to $88.1 \mathrm{mg} / \mathrm{kg}$ d.m (Table 4). The highest contents of bioavailable forms of $\mathrm{PHE}_{\mathrm{S}}$ were determined for $\mathrm{Zn}$, followed by $\mathrm{Fe}>\mathrm{Ni}>\mathrm{Pb}>\mathrm{Cd}>\mathrm{Cu}>\mathrm{Cr}$. However, it was found that PHE solubility in $0.01 \mathrm{~mol}$ $\mathrm{CaCl}_{2} / \mathrm{dm}^{3}$ was low in the studied soils and ranged from 0.10 to $3.30 \%$, in respect of their total content. PHE solubility ranged in the following order: $\mathrm{Fe}$ $(3.3 \%)>\mathrm{Cd} \quad(2.50 \%)>\mathrm{Ni} \quad(0.75 \%)>\mathrm{Zn}$ $(0.48 \%)>\mathrm{Cu}(0.19 \%)>\mathrm{Pb}(0.10 \%)>\mathrm{Cr}(0.03 \%)$ of the total concentration of those elements. Similarly, low solubility of trace elements was found in the studies of Li et al. (2014) and Kelepertzis et al. (2015), which highlighted the low extraction efficiency of the $\mathrm{CaCl}_{2}$ extraction, especially in the $\mathrm{pH}$ range characterizing the soils under consideration. The results confirmed a higher mobility of $\mathrm{Cd}$ in comparison with that of other trace elements. Many authors revealed that cadmium was very mobile and highly toxic for living organisms even at low concentrations (An 2004; Wieczorek et al. 2018). Moreover, Kim et al. (2015) suggested that the content of trace elements in soils, extracted with $0.01 \mathrm{~mol} \mathrm{CaCl}_{2} / \mathrm{dm}^{3}$, was well correlated with the response of living organisms. The studies by Zhang et al. (2010) indicated higher values of the correlation coefficients between the $\mathrm{CaCl}_{2}$-soluble fractions of soil and the contents of four of the investigated metals $(\mathrm{Cd}, \mathrm{Cu}, \mathrm{Zn}$, and $\mathrm{Pb})$ in plants. As a three-step process, bioavailability included environmental availability (availability of elements in soil); environmental bioavailability (uptake of elements by organisms); and toxicological bioavailability (negative influence of elements on organisms) (Kim et al. 2015). In the context of the described project, the bioavailability of elements was primarily influenced by soil properties. The behavior of trace elements in soils was controlled by many factors such as: $\mathrm{pH}$, redox condition, electric conductivity, organic matter content, or granulometric composition (Shaheen and Rinklebe 2014; Baran et al. 2018; Jiang et al. 2019). Generally, it was found that solubility of trace elements increased at low soil $\mathrm{pH}$ and decreased in soils with high organic carbon content. The examined soils showed slightly acidic reaction and average organic carbon content. Those factors could have influenced a lower mobility of the analyzed PHEs.

\section{Soil contamination indices}

For the soil quality determination, single and complex indices were calculated, based on the total concentrations of PHEs (Table 5). The values of the geoaccumulation index $\left(I_{\text {geo local }}\right)$, together with the local 
Table 4 PHE forms that are bioavailable for plants in the agricultural soils in southern Poland (extracted with $\mathrm{CaCl}_{2}$ )

\begin{tabular}{llllll}
\hline PHEs $(\mathrm{mg} / \mathrm{kg})$ & \multicolumn{2}{l}{ Soil $(n=30)$} & \% of mean total concentration \\
\cline { 2 - 4 } & Min & Max & Mean & Median & \\
\hline $\mathrm{Cd}$ & 0.0005 & 0.25 & 0.06 & 0.03 & 15.4 \\
$\mathrm{Cr}$ & $<$ LOQ & 0.04 & 0.005 & - & 0.03 \\
$\mathrm{Cu}$ & $<$ LOQ & 0.68 & 0.05 & 0.01 & 0.19 \\
$\mathrm{Fe}$ & 0.1 & 4.0 & 0.5 & 0.3 & 0.01 \\
$\mathrm{Ni}$ & $<$ LOQ & 1.37 & 0.11 & 0.05 & 0.96 \\
$\mathrm{~Pb}$ & 0.02 & 0.53 & 0.07 & 0.04 & 0.11 \\
$\mathrm{Zn}$ & 0.02 & 4.30 & 1.37 & 1.12 & 0.48 \\
\hline
\end{tabular}

values of geochemical background for southern Poland (Kabata-Pendias and Pendias 1999; KabataPendias 2011), indicated pollution Class 0 for As, Cd, $\mathrm{Cr}, \mathrm{Cu}, \mathrm{Hg}, \mathrm{Ni}, \mathrm{Sb}, \mathrm{Se}$, and $\mathrm{Tl}$ (practically uncontaminated), Class I for $\mathrm{Pb}$ (uncontaminated to moderately contaminated), and Class II for $\mathrm{Zn}$ (moderately contaminated). When the PHE concentrations in the upper continental crust (Rudnick and Gao 2014) were used as background values Class 0 stayed for As, Co, $\mathrm{Cr}, \mathrm{Cu}, \mathrm{Hg}, \mathrm{Ni}, \mathrm{Se}$, and $\mathrm{Tl}$, although Class II (moderately contaminated) was determined for $\mathrm{Cd}$, $\mathrm{Pb}, \mathrm{Sb}$, and $\mathrm{Zn}$. The calculations of the enrichment factor (EF), with Fe concentrations in crust soils as reference element (Kabata-Pendias 2011), indicated a severe enrichment in case of $\mathrm{Zn}, \mathrm{Pb}$, and $\mathrm{Se}$, moderately severe enrichment of $\mathrm{As}, \mathrm{Cd}$, and $\mathrm{Cu}$, moderate enrichment of $\mathrm{Hg}$, minor enrichment of $\mathrm{Co}, \mathrm{Cr}, \mathrm{Ni}$, and $\mathrm{Sb}$, and no enrichment of $\mathrm{Tl}$. When Fe contents in the loamy soils of Poland (Kabata-Pendias and Pendias 1999) were used as reference, the PHE concentrations in soil demonstrated moderately severe enrichment of $\mathrm{Zn}$, moderate enrichment of $\mathrm{Pb}$ and $\mathrm{Se}$, minor enrichment of $\mathrm{As}, \mathrm{Cd}, \mathrm{Cu}$, and $\mathrm{Hg}$, and no enrichment of $\mathrm{Co}, \mathrm{Cr}, \mathrm{Ni}, \mathrm{Sb}$, and $\mathrm{Tl}$. The contamination factor (CF) values indicated a considerable contamination with $\mathrm{Pb}$ and $\mathrm{Zn}$; moderate contamination with $\mathrm{As}, \mathrm{Cd}$, $\mathrm{Cu}, \mathrm{Hg}$, and $\mathrm{Sb}$; and low contamination with $\mathrm{Co}, \mathrm{Cr}$, $\mathrm{Ni}, \mathrm{Se}$, and Tl. The values of the single pollution index (PI) indicated a strong pollution of soils with $\mathrm{Zn}$, moderate pollution with $\mathrm{As}, \mathrm{Cd}, \mathrm{Cu}, \mathrm{Pb}$, and $\mathrm{Se}$, and lack of pollution with $\mathrm{Co}, \mathrm{Cr}, \mathrm{Hg}, \mathrm{Ni}, \mathrm{Sb}$, and $\mathrm{Tl}$. Using the threshold values (RMŚ 2016; CCME 2007) in the calculation of the $\mathrm{PI}_{\mathrm{T}}$ index, the values for each $\mathrm{PHE}$ indicated no pollution. The potential contamination index (PCI), calculated with the analyzed maximum concentrations of PHEs in soils, defined a low contamination with $\mathrm{Cr}$ and $\mathrm{Tl}$, moderate contamination with $\mathrm{Co}, \mathrm{Ni}$, and $\mathrm{Sb}$, and severe contamination with $\mathrm{As}, \mathrm{Cd}, \mathrm{Cu}, \mathrm{Hg}, \mathrm{Pb}, \mathrm{Se}$, and $\mathrm{Zn}$.

When describing the complex contamination indices, it was observed that the contamination degree $\left(\mathrm{C}_{\mathrm{deg}}\right)$ showed a considerable proportion of the investigated soil contamination, while the modified contamination degree $\left(\mathrm{mC}_{\mathrm{deg}}\right)$ denoted a low degree of contamination, the average pollution index $\left(\mathrm{PI}_{\mathrm{Avg}}\right)$ indicated a good quality of soil, the integrated pollution index (IPI) revealed moderate pollution, the pollution load index (PLI) showed no pollution, and the improved Nemerow pollution index $\left(\mathrm{PI}_{\mathrm{N}}\right)$ indicated Grade 1 of soil (safety domain). For $\mathrm{PI}_{\text {sum }}$ and $\mathrm{PI}_{\text {Tsum }}$, the calculated index values were equal to 12.3 and 2.8, respectively.

Both single and complex soil contamination indices varied depending on the background values applied (Štrbac et al. 2017). Classifications indicated the lowest soil contamination when threshold values were used as a geochemical background, lower when the background values, being specific for the country or even the region, were used, and finally the highest when general-background values were used, i.e., those referring to the continental Earth's crust. Since $\mathrm{Zn}, \mathrm{Pb}$, and $\mathrm{Cu}$ ores are mined and processed, together with the accompanying elements in southern Poland, and rock outcrops also occur on the land surface, the local background values seem to be the most appropriate to apply. Thus, it can be summarized that the $I_{\text {geo }}$ classification indicated a moderate contamination of soils by $\mathrm{Zn}$, uncontaminated to moderate contamination by $\mathrm{Pb}$, and practically no contamination by other investigated PHEs in southern Poland. The EF factor revealed a moderate severe enrichment of soils with $\mathrm{Zn}$, moderate enrichment with $\mathrm{Pb}$ and $\mathrm{Se}$, minor enrichment with $\mathrm{As}, \mathrm{Cd}, \mathrm{Cu}$, and $\mathrm{Hg}$, and no enrichment with $\mathrm{Co}, \mathrm{Cr}, \mathrm{Ni}, \mathrm{Sb}$, or $\mathrm{Tl}$. The $\mathrm{CF}$ factor 
Table 5 Contamination and ecological risk indices of the agricultural soils of southern Poland

\begin{tabular}{|c|c|c|c|c|c|c|c|c|c|c|c|c|c|c|}
\hline \multirow[t]{2}{*}{ PHEs } & \multicolumn{14}{|c|}{ Soil $(n=30)$} \\
\hline & $I_{\text {geo local }}$ & $I_{\text {geo crust }}$ & \multicolumn{2}{|r|}{$\mathrm{EF}_{\mathrm{Fe} \text { crust }}$} & \multicolumn{2}{|l|}{$\mathrm{EF}_{\mathrm{Fe} \text { loam }}$} & $\mathrm{CF}$ & PI & $\mathrm{PI}_{\mathrm{T}}$ & PCI & $\mathrm{C}_{\mathrm{deg}}$ & $\mathrm{mC}_{\mathrm{deg}}$ & $\mathrm{PI}_{\text {sum }}$ & $\overline{\mathrm{PI}_{\text {Tsum }}}$ \\
\hline As & 0 & 0 & \multicolumn{2}{|c|}{6} & \multicolumn{2}{|l|}{2} & 1 & 1.5 & 0.3 & 3.7 & \multirow[t]{12}{*}{21} & \multirow[t]{12}{*}{1.7} & \multirow[t]{12}{*}{17.4} & \multirow[t]{12}{*}{2} \\
\hline $\mathrm{Cd}$ & 0 & II & 6 & 6 & 2 & & 4 & 1.4 & 0.1 & 13 & & & & \\
\hline $\mathrm{Co}$ & 0 & 0 & 3 & 3 & $<1$ & & $<1$ & $<1$ & 0.2 & 1.5 & & & & \\
\hline $\mathrm{Cr}$ & 0 & 0 & 2 & 2 & $<1$ & & $<1$ & $<1$ & 0.1 & 0.9 & & & & \\
\hline $\mathrm{Cu}$ & 0 & 0 & 6 & 6 & 2 & & 1 & 1.4 & 0.2 & 6.0 & & & & \\
\hline $\mathrm{Hg}$ & 0 & 0 & 4 & 4 & 2 & & 1 & $<1$ & 0.0 & 9.0 & & & & \\
\hline $\mathrm{Ni}$ & 0 & 0 & 2 & 2 & $<1$ & & $<1$ & $<1$ & 0.1 & 1.1 & & & & \\
\hline $\mathrm{Pb}$ & I & II & & 11 & 4 & & 4 & 2.6 & 0.3 & 11 & & & & \\
\hline $\mathrm{Sb}$ & 0 & II & 3 & 3 & 1 & & 3 & $<1$ & 0.1 & 1.7 & & & & \\
\hline $\mathrm{Se}$ & 0 & 0 & & 13 & 4 & & 1 & 3.0 & 0.1 & 3.0 & & & & \\
\hline $\mathrm{Tl}$ & 0 & 0 & & $<1$ & $<1$ & & $<1$ & $<1$ & 0.1 & 0.4 & & & & \\
\hline $\mathrm{Zn}$ & II & II & & 19 & 6 & & 4 & 4.4 & 0.6 & 19 & & & & \\
\hline \multirow[t]{2}{*}{ PHEs } & \multicolumn{14}{|c|}{ Soil $(n=30)$} \\
\hline & $\overline{\mathrm{PI}_{\mathrm{Avg}}}$ & $\mathrm{PI}_{\text {TAvg }}$ & PLI & $\mathrm{PI}_{\mathrm{N}}$ & $\mathrm{Er}$ & HQ & & mHQ & RI & $\mathrm{HI}$ & mPELq & mERMq & ECI & $\overline{\mathrm{CSI}}$ \\
\hline As & 1.4 & 0.2 & 0.9 & 0.4 & 13.8 & 0.33 & & 0.86 & 237 & 2.0 & 0.36 & 0.27 & 2.07 & 0.28 \\
\hline $\mathrm{Cd}$ & & & & & 130 & 0.13 & & 0.40 & & & & & & \\
\hline Co & & & & & 1.42 & 0.16 & & - & & & & & & \\
\hline $\mathrm{Cr}$ & & & & & 0.41 & 0.06 & & 0.44 & & & & & & \\
\hline $\mathrm{Cu}$ & & & & & 4.75 & 0.18 & & 0.56 & & & & & & \\
\hline $\mathrm{Hg}$ & & & & & 40.0 & 0.01 & & 0.21 & & & & & & \\
\hline $\mathrm{Ni}$ & & & & & 1.22 & 0.08 & & 0.56 & & & & & & \\
\hline $\mathrm{Pb}$ & & & & & 18.8 & 0.26 & & 1.39 & & & & & & \\
\hline $\mathrm{Sb}$ & & & & & 21.5 & 0.06 & & - & & & & & & \\
\hline $\mathrm{Se}$ & & & & & - & 0.08 & & - & & & & & & \\
\hline $\mathrm{Tl}$ & & & & & 1.11 & 0.01 & & - & & & & & & \\
\hline $\mathrm{Zn}$ & & & & & 4.22 & 0.57 & & 1.77 & & & & & & \\
\hline
\end{tabular}

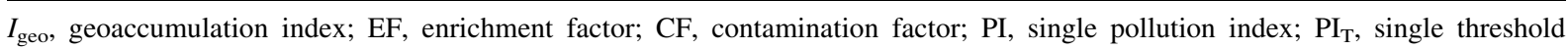
pollution index; $\mathrm{PCI}$, potential contamination index; $\mathrm{C}_{\mathrm{deg}}$, contamination degree; $\mathrm{mC}_{\mathrm{deg}}$, modified contamination degree; $\mathrm{PI}$ sum , sum of the pollution index; $\mathrm{PI}_{\mathrm{Tsum}}$, sum of the threshold pollution index; $\mathrm{PI}_{\mathrm{Avg}}$, average pollution index; $\mathrm{PI}_{\mathrm{TAvg}}$, average threshold pollution index; PLI, pollution load index; $\mathrm{PI}_{\mathrm{N}}$, improved Nemerow pollution index; Er, single index of the ecological risk factor; HQ, hazard quotient; mHQ, modified hazard quotient; RI, potential ecological risk index; HI, hazard index; mPELq, mean probable effect level quotient; mERMq, mean effect range median quotient; ECI, ecological contamination index; CSI, contamination severity index; - , not applicable

indicated a considerable contamination by $\mathrm{Pb}$ and $\mathrm{Zn}$, moderate contamination by $\mathrm{As}, \mathrm{Cd}, \mathrm{Cu}, \mathrm{Hg}$, and $\mathrm{Sb}$, and low contamination by $\mathrm{Co}, \mathrm{Cr}, \mathrm{Ni}, \mathrm{Se}$, and $\mathrm{Tl}$. The $\mathrm{PI}$ index indicated a strong pollution by $\mathrm{Zn}$, moderate pollution by $\mathrm{As}, \mathrm{Cd}, \mathrm{Cu}, \mathrm{Pb}$, and $\mathrm{Se}$, and lack of pollution by $\mathrm{Co}, \mathrm{Cr}, \mathrm{Hg}, \mathrm{Ni}, \mathrm{Sb}$, and $\mathrm{Tl}$. Finally, the $\mathrm{PI}_{\mathrm{T}}$ index indicated no pollution by each of the investigated PHEs.

\section{Ecological risk}

To determine soil quality for the purpose of edible plant cultivation, single and complex ecological risk indices were calculated (Table 5). The potential ecological risk coefficient (Er) indicated a considerable potential ecological risk of $\mathrm{Cd}$, moderate potential ecological risk of $\mathrm{Hg}$, and low potential ecological risks of $\mathrm{As}, \mathrm{Co}, \mathrm{Cr}, \mathrm{Cu}, \mathrm{Ni}, \mathrm{Pb}, \mathrm{Sb}, \mathrm{Tl}$, and $\mathrm{Zn}$. For $\mathrm{Se}$ 
the Er value was not determined due to the lack of toxic-response factor value. The hazard quotient (HQ) values denoted potential hazards in the cases of As, $\mathrm{Cd}, \mathrm{Co}, \mathrm{Cr}, \mathrm{Cu}, \mathrm{Pb}, \mathrm{Tl}$, and $\mathrm{Zn}$, although no adverse effects were determined for $\mathrm{Hg}, \mathrm{Ni}, \mathrm{Sb}$, and $\mathrm{Se}$.

The potential ecological risk indices (RI) of the analyzed PHEs indicated a moderate ecological risk. The hazard index (HI) denoted a moderate hazard from the concentrations of investigated PHEs in soils. The mHQ indices revealed a moderate severity of contamination by $\mathrm{Zn}$, low severity of contamination by $\mathrm{Pb}$, very low severity of contamination by $\mathrm{As}, \mathrm{Cu}$, and $\mathrm{Ni}$, and none to very low severity of contamination by $\mathrm{Cd}, \mathrm{Cr}$, or $\mathrm{Hg}$. For $\mathrm{Co}, \mathrm{Sb}, \mathrm{Se}$, and $\mathrm{Tl}$, the $\mathrm{mHQ}$ values were not determined due to the lack of TEL, PEL, and SEL values in the literature. The mean probable effect level quotient (mPELq) of the investigated PHEs indicated a medium-low degree of contamination, with the probability of being toxic equal to $8 \%$, while the mean effect range median quotient (mERMq) pointed at a medium-low priority site, with the probability of being toxic equal to $9 \%$. The ecological contamination index (ECI) revealed that the investigated soils were at the border between uncontaminated and uncontaminated to slightly contaminated (the calculated ECI value: 2.07). Based on their percentage contributions to ECI, the PHE values were ordered in the following decreasing sequence: $\mathrm{Zn}>\mathrm{Pb}>\mathrm{As}>\mathrm{Cu}>\mathrm{Ni}>\mathrm{Cr}>\mathrm{Cd}>\mathrm{Hg}$. Finally, the contamination severity index (CSI) value equal to 0.28 indicated that the studied soils of the southern Poland were uncontaminated by the PHEs under consideration.

\section{Correlation and PCA}

The above-described soil quality and ecological indicators were confirmed by the results of the correlation analysis (Table 6). In the respective studies, $\mathrm{pH}$ showed no significant correlation with the contents of all the elements. The element content was significantly either positively ( $\mathrm{Al}, \mathrm{Fe}, \mathrm{Co}, \mathrm{Cu}, \mathrm{Cr}, \mathrm{Sb}$, and $\mathrm{Zn}$ ) or negatively (Ni) correlated with the clay content. A high positive correlation between the elements and the clay content might suggest that the clay fraction played a dominant role in the mobility and sorption of the analyzed elements. Moreover, a lot of significant positive correlations between the elements and clay might point at the natural sources of
PHE soils. Besides, a significantly positive correlation between the $\mathrm{Pb}$ content and $C_{\text {org }}$ was observed. It is widely known that a significant positive correlation between the elements indicates that they have the same sources and display a similar behavior during transport (Baran and Wieczorek 2015). A lot of positively correlated pairs of elements were observed (Table 6). However, negative correlations were observed in $\mathrm{Cd}, \mathrm{Ni}, \mathrm{As}$, and $\mathrm{Tl}$ in the studied soils. The negative correlations between some individual pairs of trace elements indicated that they might have come from various sources, and were usually associated with anthropogenic origin (Baran and Wieczorek 2015; Wieczorek et al. 2018). While analyzing the relationship between the contents of individual elements on the one hand and $\mathrm{Fe}$ and $\mathrm{Al}$ on the other hand, the latter were treated separately, while the positive correlation between the $\mathrm{Al}$ and $\mathrm{Fe}$ contents and the investigated PHEs suggested the elements' natural content in the soil. The positive correlations between $\mathrm{Fe}$ and $\mathrm{Al}$ on the one hand and $\mathrm{Co}, \mathrm{Cu}, \mathrm{Hg}, \mathrm{Sb}, \mathrm{Zn}, \mathrm{Cr}$, and $\mathrm{Pb}$ on the other hand were indicated in the studies that confirmed the natural origin of the elements (Table 6). The negative correlations between the $\mathrm{Fe}$ and $\mathrm{Al}$ contents and the $\mathrm{Cd}, \mathrm{Ni}, \mathrm{As}$, and $\mathrm{Tl}$ ones might point at anthropogenic origin of the investigated PHEs. However, it should be noted that the correlations obtained for the majority of relations were either very low, low, or medium. The principal component analysis (PCA) confirmed the above observations and extracted two principal components (PCs), explaining $44.88 \%$ of the total variance of the dataset. PC1, explaining $26.21 \%$ of the total variance, had a significant positive loading on clay, $\mathrm{Al}, \mathrm{Fe}, \mathrm{Co}$, and $\mathrm{Sb}$. Those results revealed that PC1, covering the PHE contents in the soil, had natural sources. Moreover, the high loading for clay and Fe suggested the importance of those minerals in binding trace element ions in the studied soils. PC2 explained $18.66 \%$ of the total variance, with a strong positive loading on $\mathrm{As}, \mathrm{Ni}, \mathrm{Cd}$, $\mathrm{Tl}$ (Table 7). The combination of trace elements in PC2 suggested their anthropogenic origin and sources. For example, $\mathrm{Ni}$ and $\mathrm{Cd}$ have been commonly used in industry and their high quantities can be found on the areas surrounding developed urban areas. Moreover, the high $\mathrm{Ni}$ content in the environment is an important indicator of recent anthropogenic pollution (de CastroCatalà et al. 2016). The described studies were conducted in southern Poland, in the region 
Table 6 Relationships between the soil sample properties

\begin{tabular}{|c|c|c|c|c|c|c|c|c|c|c|c|c|c|c|c|}
\hline$n=30$ & $\mathrm{pH}$ & clay & $C_{\text {org }}$ & $\mathrm{Al}$ & $\mathrm{Fe}$ & As & $\mathrm{Cd}$ & Co & $\mathrm{Cr}$ & $\mathrm{Cu}$ & $\mathrm{Hg}$ & $\mathrm{Ni}$ & $\mathrm{Pb}$ & $\mathrm{Sb}$ & $\mathrm{Tl}$ \\
\hline Clay & 0.07 & & & & & & & & & & & & & & \\
\hline$C_{\mathrm{org}}$ & 0.07 & 0.01 & & & & & & & & & & & & & \\
\hline $\mathrm{Al}$ & 0.12 & 0.55 & - & & & & & & & & & & & & \\
\hline $\mathrm{Fe}$ & 0.15 & 0.64 & 0.07 & 0.79 & & & & & & & & & & & \\
\hline As & 0.23 & - & 0.12 & - & - & & & & & & & & & & \\
\hline $\mathrm{Cd}$ & 0.25 & - & 0.06 & - & - & 0.58 & & & & & & & & & \\
\hline Co & - & 0.48 & - & 0.71 & 0.78 & - & - & & & & & & & & \\
\hline $\mathrm{Cr}$ & 0.08 & 0.49 & - & 0.29 & 0.26 & 0.26 & - & 0.06 & & & & & & & \\
\hline $\mathrm{Cu}$ & 0.21 & 0.54 & 0.30 & 0.37 & 0.59 & - & - & 0.41 & 0.48 & & & & & & \\
\hline $\mathrm{Hg}$ & - & 0.17 & 0.02 & 0.24 & 0.40 & 0.04 & - & 0.31 & 0.05 & 0.11 & & & & & \\
\hline $\mathrm{Ni}$ & - & - & 0.13 & - & - & 0.38 & 0.68 & - & - & - & 0.10 & & & & \\
\hline $\mathrm{Pb}$ & 0.06 & 0.28 & 0.39 & 0.12 & 0.35 & 0.10 & - & 0.13 & 0.29 & 0.48 & 0.17 & 0.03 & & & \\
\hline $\mathrm{Sb}$ & 0.24 & 0.46 & - & 0.39 & 0.51 & 0.16 & - & 0.35 & 0.54 & 0.33 & 0.34 & - & - & & \\
\hline $\mathrm{Tl}$ & 0.07 & - & 0.21 & - & - & 0.62 & 0.80 & - & - & - & 0.13 & 0.66 & 0.04 & 0.06 & \\
\hline $\mathrm{Zn}$ & 0.26 & 0.71 & 0.17 & 0.34 & 0.44 & - & - & 0.22 & 0.41 & 0.58 & 0.01 & - & 0.46 & 0.39 & - \\
\hline
\end{tabular}

Bold indicates satistically significant at $p<0.05 ; 0<r<0.3$ very low correlation; $0.3 \leq r<0.5$ low correlation; $0.5 \leq r<0.7$ medium correlation; $0.7 \leq r<0.9$ strong correlation; $0.9 \leq r<1$ very strong correlation; - , not applicable

characterized by a large diversity of geological structures and agricultural and industrial development, as well as anthropogenic pressures. Southern Poland is the area of intense coal mining and processing in the Silesia (Szczepańska and Twardowska 1999; Jończy and Gawor 2017), mining and processing of $\mathrm{Zn}$ and $\mathrm{Pb}$ ores in the Olkusz area (Krzaklewski et al. 2004; Postawa and Motyka 2019), and of $\mathrm{Cu}$ ores in the Lower Silesia (Potysz et al. 2018). Besides the urban agglomerations of Kraków and Wrocław, the Upper and Lower Silesia Regions are also located in southern Poland, with significant contamination of the environment due to coal-burning heating plant operations, as well as wood and waste burning in poor quality stoves (Kobza et al. 2018), not to mention huge local traffic (Adamiec 2017). Atmospheric deposition of heavy metals in Poland is one of the highest in Europe, with the value of $68.2 \mathrm{mg} / \mathrm{m}^{2} /$ year (Shi et al. 2018). Also, intense animal and vegetable production introduces PHEs to soils (Dach and Starmans 2005). On the other hand, southern Poland is also the land where the most productive soils occur in the so-called loess belt spreading from Ukraine to Germany across southern Poland (Labaz et al. 2019).
Table 7 A component matrix for variables $(n=30)$

\begin{tabular}{lcr}
\hline Variables & PCA 1 & PCA 2 \\
\hline $\mathrm{pH}_{\mathrm{KCl}}$ & 0.205 & 0.190 \\
$\mathrm{Clay}$ & $\mathbf{0 . 7 5 9}$ & -0.148 \\
$C_{\text {org }}$ & 0.225 & 0.081 \\
$\mathrm{Al}$ & $\mathbf{0 . 6 3 4}$ & -0.270 \\
$\mathrm{Fe}$ & $\mathbf{0 . 7 9 4}$ & -0.140 \\
$\mathrm{As}$ & 0.069 & $\mathbf{0 . 7 3 3}$ \\
$\mathrm{Cd}$ & 0.042 & $\mathbf{0 . 8 6 8}$ \\
$\mathrm{Co}$ & $\mathbf{0 . 6 7 8}$ & -0.292 \\
$\mathrm{Cr}$ & $\mathbf{0 . 5 1 4}$ & 0.074 \\
$\mathrm{Cu}$ & 0.497 & -0.041 \\
$\mathrm{Hg}$ & 0.488 & 0.201 \\
$\mathrm{Ni}$ & -0.283 & $\mathbf{0 . 8 1 1}$ \\
$\mathrm{Pb}$ & 0.311 & 0.261 \\
$\mathrm{Sb}$ & $\mathbf{0 . 7 1 7}$ & 0.312 \\
$\mathrm{Tl}$ & 0.112 & $\mathbf{0 . 8 8 2}$ \\
$\mathrm{Zn}$ & $\mathbf{0 . 5 6 0}$ & -0.254 \\
Eigenvalue & 4.194 & 2.987 \\
Total variance \% & 26.21 & 18.66 \\
Cumulative variance $\%$ & 26.21 & 44.88 \\
\hline
\end{tabular}

Factor loadings exceeding 0.5 are shown in bold 
Human health risk assessment

The values of calculated non-carcinogenic and carcinogenic risk arising from ingestion, dermal contact, and inhalation pathways, under residential, recreational, and agricultural (worker) scenarios are presented in Table 8. Under each exposure scenario, both non-carcinogenic and carcinogenic risk values were higher for children than for adults. The total noncarcinogenic risks were equal to $1.63 \mathrm{E}-01$ for adults and $4.55 \mathrm{E}-01$ for children under the residential scenario; 2.88E-01 for adults and 6.69E-01 for children under the recreational scenario; and $1.03 \mathrm{E}-01$ for adult workers under the agricultural scenario. Therefore, for both adults and children under the three assumed exposure scenarios, the total noncarcinogenic risk values were $<1$; thus, adverse health effects were not likely to be observed. The total carcinogenic risks (of carcinogenic PHEs investigated in the study) were equal to $1.62 \mathrm{E}-05$ for adults and $6.39 \mathrm{E}-05$ for children under the residential scenario, 5.41E-06 for adults and 2.46E-05 for children under the recreational scenario, and $1.45 \mathrm{E}-05$ for adult workers under the agricultural scenario. Therefore, for both adults and children under the three exposure scenarios, the total carcinogenic risk values were at the acceptable levels that were set to be equal to $1 \times 10^{-4}$ for the sum of carcinogenic PHEs. Under all the exposure scenarios, non-carcinogenic and carcinogenic risks decreased in the following order of exposure pathways: ingestion $>$ dermal contact $>$ inhalation of soil particles, for both adults and children, with the exception of adults under the residential scenario where the carcinogenic risk decreased as follows: dermal contact $>$ ingestion $>$ inhalation of soil particles. For the inhalation exposure pathway under each scenario and for adults and children, the non-carcinogenic risks decreased as follows: $\mathrm{Co}>\mathrm{As}>\mathrm{Cr}(\mathrm{VI})>\mathrm{Ni}>\mathrm{Cd}>\mathrm{Hg}>\mathrm{Se}$. For the ingestion pathway under the residential scenario for adult and children and under the agricultural scenario for adult workers, non-carcinogenic risks decreased as follows: $\mathrm{Pb}>\mathrm{Co}>\mathrm{As}>\mathrm{Tl}>$ $\mathrm{Cr}(\mathrm{VI})>\mathrm{Sb}>\mathrm{Zn}>\mathrm{Cu}>\mathrm{Ni}>\mathrm{Cd}>\mathrm{Hg}>\mathrm{Se}>$ $\mathrm{Cr}(\mathrm{III})$. For the dermal contact by adults and children under the residential scenario, for adults under the recreational scenario, and for adult workers under the agricultural scenario, the decreasing order was the following: $\quad \mathrm{Cr}(\mathrm{VI})>\mathrm{As}>\mathrm{Pb}>\mathrm{Sb}>\mathrm{Co}>\mathrm{Cd}>$
$\mathrm{Ni}>\mathrm{Tl}>\mathrm{Hg}>\mathrm{Cr}(\mathrm{III})>\mathrm{Zn}>\mathrm{Cu}>\mathrm{Se}$. Under the recreational scenario for adults and children in the ingestion pathway and for children in the dermal contact exposure, the decreasing order was the following: $\quad \mathrm{As}>\mathrm{Pb}>\mathrm{Co}>\mathrm{Tl}>\mathrm{Cr}(\mathrm{VI})>\mathrm{Sb}>$ $\mathrm{Zn}>\mathrm{Cu}>\mathrm{Ni}>\mathrm{Cd}>\mathrm{Hg}>\mathrm{Se}>\mathrm{Cr}$ (III). For the carcinogenic risk of the inhalation exposure under all the exposure scenarios, the decreasing order of investigated PHEs was as follows: $\mathrm{Cr}(\mathrm{VI})>\mathrm{Co}>$ As $>\mathrm{Ni}>\mathrm{Cd}$, for both adults and children, whereas in the case of ingestion and dermal contact by adults and children, the decreasing order was the following: $\mathrm{Cr}(\mathrm{VI})>\mathrm{As}>\mathrm{Pb}$.

\section{Uncertainties in HHRA}

The calculated HHRA values were assumed due to the fact that exposure parameters were equivalent to either default data or certain assumptions adopted for research purposes. Thus, especially in the case of the recreational scenario, the risk values depended strongly on real exposition. In the calculations, the RBA and GIABS factors were used to determine bioavailable contents of PHEs (see Table 2); however, such factors were not available for all PHEs; thus, the risk values may have been overestimated. Only twelve PHEs as non-carcinogenic were analyzed and, out of them, only five in the inhalational pathway and three in ingestion and dermal contact were considered to be carcinogenic; thus, the real total non-carcinogenic and carcinogenic risks may have been underestimated. Under the residential scenario, where the highest carcinogenic risk in the dermal contact pathway was observed, the risk may have been caused by the assumption of the total $\mathrm{Cr}$ content in soil ascribed to $\mathrm{Cr}(\mathrm{VI})$ and that obviously caused risk value overestimation.

\section{Discussion}

The research on agricultural soils in southern Poland was performed in 2015 and 2016, in the areas where edible plants had been cultivated and subsequently sold on fresh produce markets by the farmers. The concentration of neither of the investigated PHEs (As, $\mathrm{Cd}, \mathrm{Cr}, \mathrm{Co}, \mathrm{Cu}, \mathrm{Hg}, \mathrm{Ni}, \mathrm{Pb}, \mathrm{Sb}, \mathrm{Se}, \mathrm{Tl}$, and $\mathrm{Zn}$ ) exceeded permissible concentrations, in reference to either the Polish law standards or the Canadian 


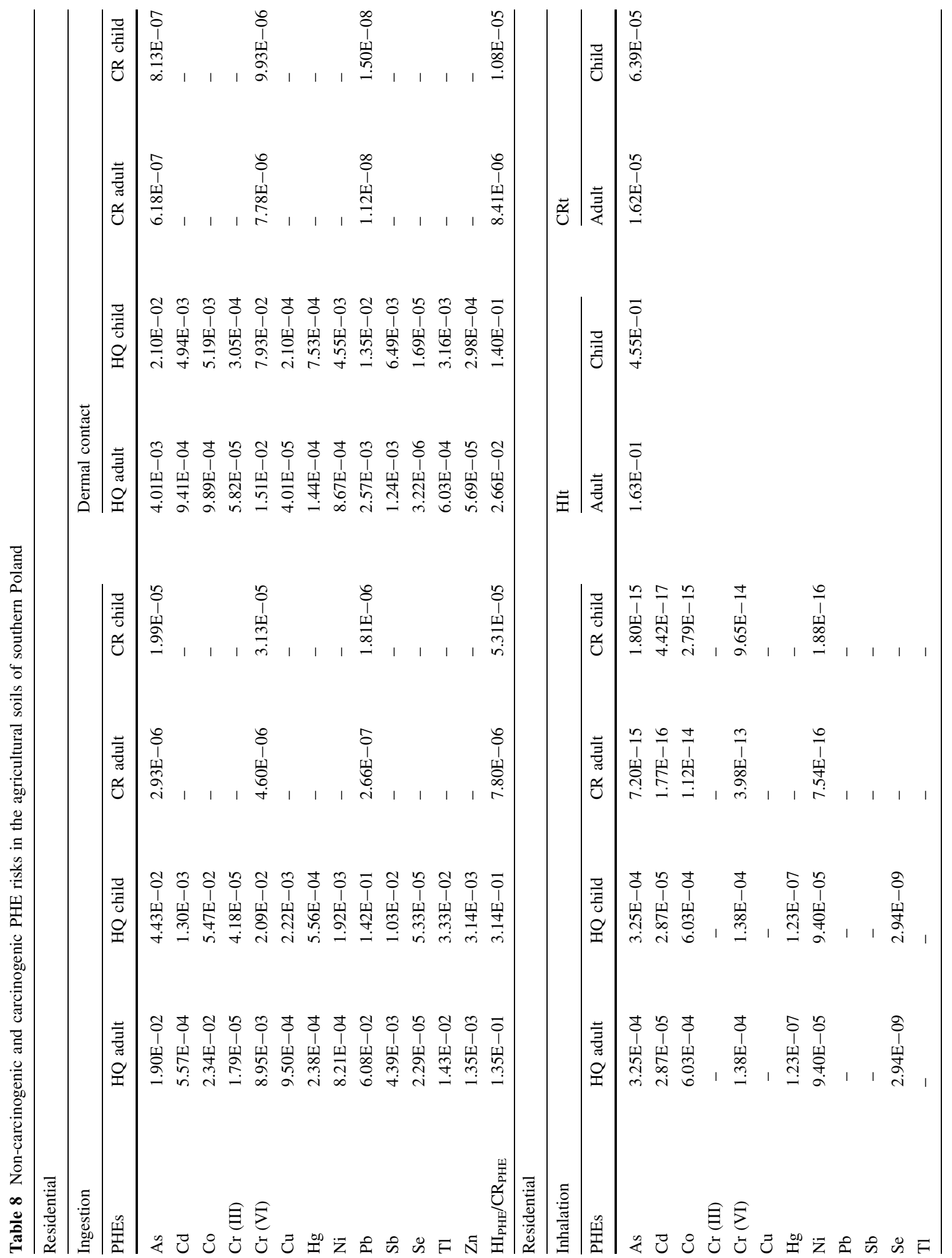




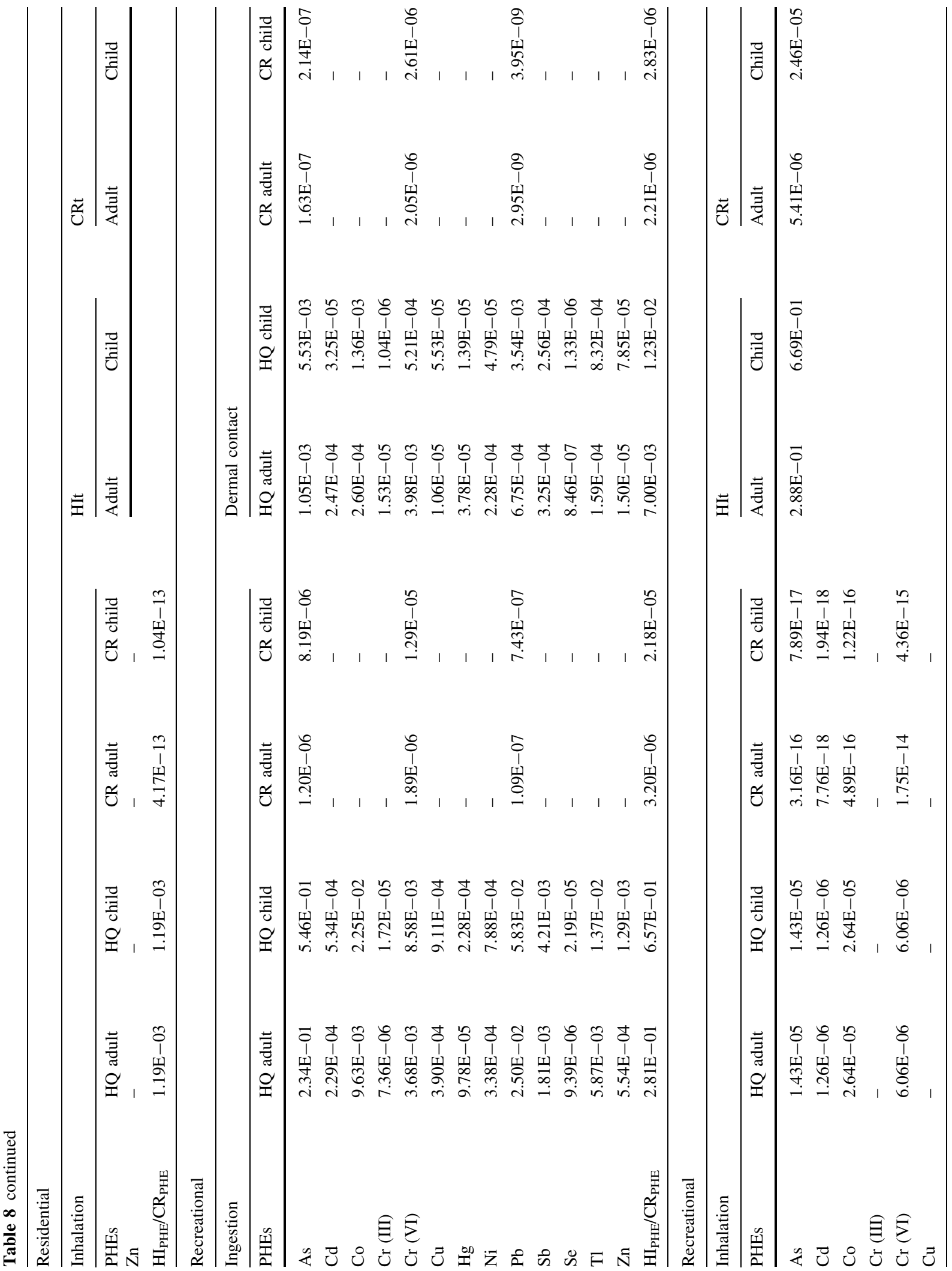




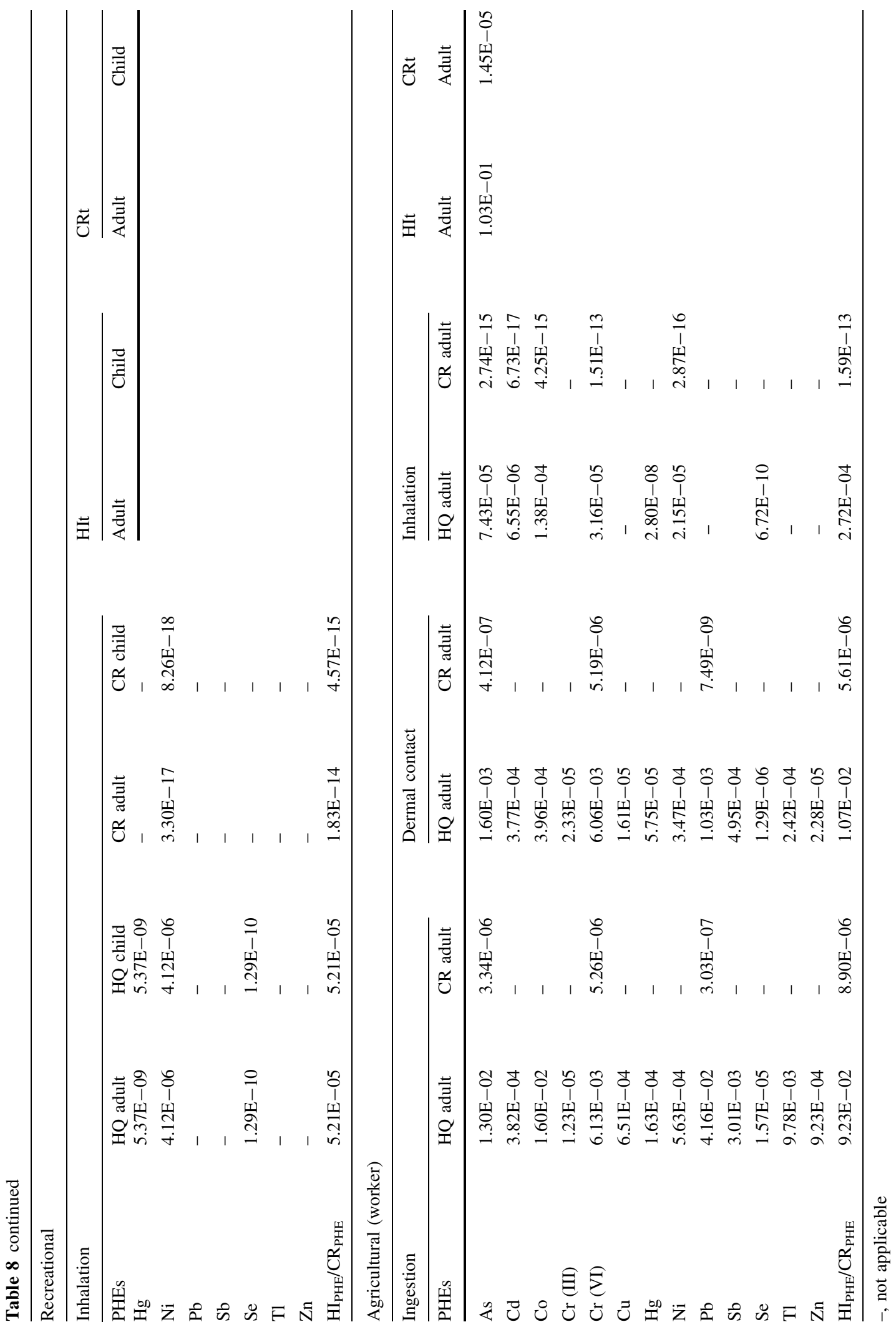


guidelines for the protection of environmental and human health. Thus, the investigated soils met the legal requirements for the cultivation of edible plants under the Polish law and there was no threat to human health or the environment, in reference to the applicable soil guidelines. The results were in accordance with the findings of the last 20-year National Monitoring System of Arable Soils program in Poland that revealed that the PHE contents in the majority of arable soils were low and do not adversely affect soil functions for high-quality food production (Smreczak et al. 2018). The mean $\mathrm{Al}$ concentration was equal to $0.65 \%$ and that of $\mathrm{Fe}$ to $0.98 \%$. The mean PHE contents were the following $(\mathrm{mg} / \mathrm{kg})$ : As $6.64, \mathrm{Cd}$ 0.39, Co 4.92, Cr 18.8, Cu 26.5, Hg 0.05, Ni 11.5, Pb 63.8, Sb 1.23, Tl 0.10, Zn 283, and Se below the limit of quantification. The results obtained in the current confirmed the findings of other researchers on the PHE contents in the arable soils of southern Poland (Loska et al. 2003, 2004; Baran and Wieczorek 2015; Mazurek et al. 2017; Labaz et al. 2019; Baran et al. 2018; Gałuszka et al. 2018; Pająk et al. 2018; Piekut et al. 2018; Wieczorek et al. 2018; Mazurek et al. 2019; Waroszewski et al. 2019). Nevertheless, the direct comparison of data between different studies should be made with caution due to time and methods differences.

The bioavailable element contents of PHEs, extracted in $\mathrm{CaCl}_{2}$, were the following: $\mathrm{Cd} 15.4 \%$, $\mathrm{Cr} 0.03 \%$, Cu $0.19 \%$, Fe $0.01 \%$, Ni $0.96 \%$, Pb 0.11\%, and $\mathrm{Zn} 0.48 \%$ of the total PHE content. Taking under consideration low extraction efficiency of $\mathrm{CaCl}_{2}$, which, however, indicated significant mobility of cadmium (Ali et al. 2018), further more detailed study on PHE mobility and availability of investigated arable soils seems to be justified.

Quartz was the main mineral found in the investigated soils, followed by small amounts of feldspars, illite, montmorillonite, kaolinite, and goethite. Due to a very similar mineral composition of the investigated soil samples, one could conclude that the differences identified in the PHE contents could be associated with the anthropogenic activities rather than the mineral composition of the investigated soils. High positive $(\mathrm{Al}, \mathrm{Fe}, \mathrm{Co}, \mathrm{Cu}, \mathrm{Cr}, \mathrm{Sb}$, and $\mathrm{Zn}$ ) and negative $(\mathrm{Ni})$ correlations between the elements and the clay content may have indicated that the clay fraction played a dominant role in the PHE mobility and sorption. The positive correlations observed might also indicate the origin of $\mathrm{Co}, \mathrm{Cu}, \mathrm{Hg}, \mathrm{Sb}, \mathrm{Zn}, \mathrm{Cr}$, and $\mathrm{Pb}$ from natural sources in the investigated agricultural soils. On the other hand, the negative correlations between some individual pairs of trace elements might point at the anthropogenic origin of $\mathrm{Cd}, \mathrm{Ni}, \mathrm{As}$, and $\mathrm{Tl}$ in agricultural soils.

As mentioned above the majority of arable soils in Poland were not contaminated with PHEs according to legal requirements. However, locally or even regionally there might be areas where exceedance of PHEs content might occur. Then ecological and health risk assessment procedures should be applied. The $I_{\text {geo }}$ classification indicated a moderate contamination of soils by $\mathrm{Zn}$, uncontaminated to moderate contamination by $\mathrm{Pb}$, and no contamination by other investigated PHEs. The EF factor revealed a moderate severe enrichment with $\mathrm{Zn}$, moderate enrichment with $\mathrm{Pb}$ and $\mathrm{Se}$, minor enrichment with $\mathrm{As}, \mathrm{Cd}, \mathrm{Cu}$, and $\mathrm{Hg}$, and no enrichment with $\mathrm{Co}, \mathrm{Cr}, \mathrm{Ni}, \mathrm{Sb}$, or $\mathrm{Tl}$. The $\mathrm{CF}$ factor pointed at a considerable contamination by $\mathrm{Pb}$ and $\mathrm{Zn}$, moderate contamination by $\mathrm{As}, \mathrm{Cd}, \mathrm{Cu}, \mathrm{Hg}$, and $\mathrm{Sb}$, and low contamination by $\mathrm{Co}, \mathrm{Cr}, \mathrm{Ni}, \mathrm{Se}$, and $\mathrm{Tl}$. The $\mathrm{PI}$ index indicated a strong pollution by $\mathrm{Zn}$, moderate pollution by $\mathrm{As}, \mathrm{Cd}, \mathrm{Cu}, \mathrm{Pb}$, and $\mathrm{Se}$, and lack of pollution by $\mathrm{Co}, \mathrm{Cr}, \mathrm{Hg}, \mathrm{Ni}, \mathrm{Sb}$, or Tl. Finally, the $\mathrm{PI}_{\mathrm{T}}$ index indicated a lack of pollution by each PHE. The Er coefficient indicated a considerable potential ecological risk of $\mathrm{Cd}$, moderate potential ecological risk of $\mathrm{Hg}$, and low potential ecological risk of As, Co, $\mathrm{Cr}, \mathrm{Cu}, \mathrm{Ni}, \mathrm{Pb}, \mathrm{Sb}, \mathrm{Tl}$, and $\mathrm{Zn}$. The mHQ values revealed moderate severity of contamination by $\mathrm{Zn}$, low severity by $\mathrm{Pb}$, very low severity by $\mathrm{As}, \mathrm{Cu}$, and $\mathrm{Ni}$, and none to very low severity by $\mathrm{Cd}, \mathrm{Cr}$, or $\mathrm{Hg}$. The values of the mPELq quotient indicated a mediumlow degree of contamination and the mERMq quotient a medium-low priority site.

The value of the ECI index classified the analyzed soils at the border between the uncontaminated and uncontaminated to slightly contaminated. The CSI index value indicated that the studied soils were not contaminated by the investigated PHEs in the southern Poland.

The total non-carcinogenic risks were equal to $1.63 \mathrm{E}-01$ for adults and $4.55 \mathrm{E}-01$ for children under the residential scenario, $2.88 \mathrm{E}-01$ for adults and $6.69 \mathrm{E}-01$ for children under the recreational scenario, and $1.03 \mathrm{E}-01$ for adult workers under the agricultural scenario. For both adults and children under the three assumed exposure scenarios, the total non- 
carcinogenic risk values were $<1$; thus, adverse health effects were not likely to be observed. The total carcinogenic risk of $\mathrm{As}, \mathrm{Cr}(\mathrm{VI})$, and $\mathrm{Pb}$ in ingestion and dermal contact exposure and of $\mathrm{As}, \mathrm{Cd}$, $\mathrm{Co}, \mathrm{Cr}(\mathrm{VI})$, and $\mathrm{Ni}$ in inhalation exposure was equal to $1.62 \mathrm{E}-05$ for adults and $6.39 \mathrm{E}-05$ for children under the residential scenario, $5.41 \mathrm{E}-06$ for adults and $2.46 \mathrm{E}-05$ for children under the recreational scenario, and $1.45 \mathrm{E}-05$ for adult workers under the agricultural scenario. For both adults and children under the three exposure scenarios, the total carcinogenic risk values were at the acceptable levels that were set to be equal to $1 \times 10^{-4}$ for the sum of carcinogenic PHEs.

\section{Conclusions}

The studies revealed that investigated agricultural soils were fully suitable for edible plants production. The permissible total PHE concentrations were not exceeded. Despite the increasing environmental pollution with PHEs, especially in Śląskie and Małopolskie Regions of the southern Poland, the quality of the arable soils was not lowered due to several reasons. The soils in Poland were generally not significantly contaminated, although it should be noted that there were point pollution sources of soils with PHEs, what was observed even in the investigated area. Moreover, it is worth remembering that agricultural soils were intensively used for the plant production; thus, some of investigated elements were taken up by plants and removed at once with the crop yield. Thus, agricultural soils should remain under special supervision to maintain their quality for food production. Finally, most of analyzed PHEs indicated low mobility due to properties of the studied soils. However, the next step of the research should be the analysis of the PHE bioavailability of these particular soils. To sum up, the study of total and soluble forms of PHE contents in the arable soils, with the ecological and health risk implications, was an important step in determining the potential transfer of PHEs in the soil-plant-human chain. The applied soil quality and contamination indices managed to reveal the PHEs content in soils in various conditions. The achieved results could be useful in planning, risk assessment, and decision making in the environmental management and for improving the ecosystem and human health.
Acknowledgements This research was supported within the framework of Statutory Research Grant No. 11.11.140.199 and Dean's Grant No. 15.11.140.357 by the AGH University of Science and Technology.

Open Access This article is distributed under the terms of the Creative Commons Attribution 4.0 International License (http:// creativecommons.org/licenses/by/4.0/), which permits unrestricted use, distribution, and reproduction in any medium, provided you give appropriate credit to the original author(s) and the source, provide a link to the Creative Commons license, and indicate if changes were made.

\section{References}

Adamiec, E. (2017). Chemical fractionation and mobility of traffic-related elements in road environments. Environmental Geochemistry and Health, 39(6), 1457-1468.

Ali, A. S. M., Ahmed, H. A. M., Emara, H. A. E.-A., Janjua, M. N., \& Alhafez, N. (2018). Estimation and bio-availability of toxic metals between soils and plants. Polish Journal of Environmental Studies, 28(1), 15-24.

An, Y. J. (2004). Ecotoxicity assessment using cadmium sensitive plants. Environmental Pollution, 127, 21-26.

Banna, J. C., Gilliland, B., Keefe, M., \& Zheng, D. (2016). Cross-cultural comparison of perspectives on healthy eating among Chinese and American undergraduate students. MBC Public Health, 16, 1015.

Baran, A., Czech, T., \& Wieczorek, J. (2014). Chemical properties and toxicity of soils contaminated by mining activity. Ecotoxicology, 2(7), 1234-1244.

Baran, A., \& Wieczorek, J. (2015). Application of geochemical and ecotoxicity indices for assessment of heavy metals content in soils. Archives of Environmental Protection, 41(2), 54-63.

Baran, A., Wieczorek, J., Mazurek, R., Urbański, K., \& Klimkowicz-Pawlas, A. (2018). Potential ecological risk assessment and predicting zinc accumulation in soils. Environmental Geochemistry and Health, 40(1), 435-450.

Barsova, N., Yakimenko, O., Tolpeshta, I., \& Motuzova, G. (2019). Current state and dynamics of heavy metal soil pollution in Russian Federation-A review. Environmental Pollution, 24, 200-207.

Cabral-Pinto, M. M. S., Marinho-Reis, P., Almeida, A., Ordens, C. M., Silva, M. M. V. G., Freitas, S., et al. (2018). Human predisposition to cognitive impairment and its relation with environmental exposure to potentially toxic elements. Environmental Geochemistry and Health, 40(5), 1767-1784.

Canadian Council of Ministers of the Environment (CCME). (2007). Canadian soil quality guidelines for the protection of environmental and human health: summary tables. Updated September, 2007. In Canadian environmental quality guidelines, 1999. Canadian Council of Ministers of the Environment, Winnipeg.

Dach, J., \& Starmans, D. (2005). Heavy metals balance in Polish and Dutch agronomy: Actual state and previsions for the 
future. Agriculture, Ecosystems \& Environment, 107, 309-316.

de Castro-Català, N., Kuzmanovic, M., Roig, N., Sierra, J., Ginebreda, A., Barceló, D., et al. (2016). Ecotoxicity of sediments in rivers: Invertebrate community, toxicity bioassays and the toxic unit approach as complementary assessment tools. Science of the Total Environment, 540, 297-306.

de Oliviera, L. C., Ribeiro, C. A., Rosa, A. H., Botero, W. G., Rocha, J. C., Romão, L. P. C., et al. (2009). Thermal decomposition kinetics of humic substances extracted from mid-Rio Negro (Amazon Basin) soil samples. Journal of the Brazilian Chemical Society, 20(6), 1135-1141.

Dziubanek, G., Baranowska, R., Ćwieląg-Drabek, M., Spychała, A., Piekut, A., Rusin, M., et al. (2017). Cadmium in edible plants from Silesia, Poland, and its implications for health risk in populations. Ecotoxicology and Environmental Safety, 142, 8-13.

Dziubanek, G., Piekut, A., Rusin, M., Baranowska, R., \& Hajok, I. (2015). Contamination of food crops grown on soils with elevated heavy metals content. Ecotoxicology and Environmental Safety, 118, 183-189.

European Food Safety Authority (EFSA). (2010). EFSA panel on contaminants in the food chain (CONTAM), Scientific Opinion on Lead in Food. EFSA Journal, 8(4), 1570.

Gałuszka, A., Migaszewski, Z. M., Dołęgowska, S., \& Michalik, A. (2018). Geochemical anomalies of trace elements in unremediated soils of Mt. Karczówka, a historic lead mining area in the city of Kielce. Poland. Science of the Total Environment, 639, 397-405.

GIOŚ. (2017). Chemical monitoring of arable soils, IUNG Institute of Soil Science and Plant Cultivation in Puławy, Main Inspectorate of Environmental Protection. (in Polish). http://www.gios.gov.pl/chemizm_gleb/index. php?mod=monit. Accessed 23 Feb 2019.

GUS. (2016). Use of grounds and surface area in the year 2015. Warszawa: Central Statistical Office. (in Polish).

Huang, Y., Wang, Y., Wang, W., Li, T., He, Z., \& Yang, X. (2019). Current status of agricultural soil pollution by heavy metals in China: A meta-analysis. Science of the Total Environment, 651, 3034-3042.

IARC. (2012). International Agency for Research on Cancer (2012). A review of human carcinogens: arsenic, metals, fibres, and dusts: chromium (VI) compounds. IARC Monographs Vol. 100C-9. International Agency for Research on Cancer (IARC). http://monographs.iarc.fr/ ENG/Monographs/vol100C/mono100C-9.pdf. Accessed $10 / 02 / 2019$.

Inengite, A. K., Abasi, C. Y., \& Walter, C. (2015). Application of pollution indices for the assessment of heavy metal pollution in flood impacted soil. International Research Journal of Pure \& Applied Chemistry, 8(3), 175-189.

ISO 10694:1995. Soil quality-Determination of organic and total carbon after dry combustion (elementary analysis).

IUSS Working Group WRB. (2015). World Reference Base for Soil Resources 2014, update 2015. International soil classification system for naming soils and creating legends for soil maps. World Soil Resources Reports No. 106. Rome: FAO.

Izquierdo, M., De Miguel, E., Ortega, M. F., \& Mingot, J. (2015). Bioaccessibility of metals in human health risk assessment in community urban gardens. Chemosphere, 135, 312-318.

Jiang, B., Ma, Y., Zhu, G., \& Li, J. (2019). A new model describing copper dose-toxicity to tomato and bok choy growth in a wide range of soils. International Journal of Environmental Research and Public Health, 16, 264. https://doi.org/10.3390/ijerph16020264.

Jończy, I., \& Gawor, Ł. (2017). Coal mining and post-metallurgic dumping grounds and their connections with exploitation of raw materials in the region of Ruda Ślaska. Archives of Mining Sciences, 62(2), 301-311.

Journal of Laws. (1951). Act of 18 January 1951 on non-working days (OJ 1951, no 4, item 28) (in Polish).

Kabata-Pendias, A. (2011). Trace elements in soils and plants (4th ed.). Boca Raton: CRC Press, Taylor \& Francis Group.

Kabata-Pendias, A., \& Pendias, H. (1999). Biogeochemistry of trace elements. Warszawa: Wydawnictwo Naukowe PWN. (in Polish).

Kapetanaki, A. B., Brennan, D. R., \& Caraher, M. (2014). Social marketing and healthy eating: Findings from young people in Greece. International Review on Public and Nonprofit Marketing, 11, 161-180.

Kelepertzis, E., Paraskevopoulou, V., Argyraki, A., Fligos, G., \& Chalkiadaki, O. (2015). Evaluation of single extraction procedures for the assessment of heavy metal extractability in citrus agricultural soil of a typical Mediterranean environment (Argolida, Greece). Journal of Soils and Sediments, 15, 2265-2275.

Kim, R. Y., Yoon, J. K., Kim, T. S., Yang, J. E., Owens, G., \& Kim, K. R. (2015). Bioavailability of heavy metals in soils: Definitions and practical implementation-a critical review. Environmental Geochemistry and Health, 37(6), 1041-1061.

Klimek-Kopyra, A., Baran, A., Zając, T., \& Kulig, B. (2015). Effects of heavy metals from polluted soils on the roots and nodules formation. Bulgarian Journal of Agricultural Science, 21(2), 295-299.

Kobza, J., Geremek, M., \& Dul, L. (2018). Characteristics of air quality and sources affecting high levels of PM10 and PM2.5 in Poland, Upper Silesia urban area. Environmental Monitoring and Assessment, 190(9), 515.

Kowalska, J. B., Mazurek, R., Gąsiorek, M., \& Zaleski, T. (2018). Pollution indices as useful tools for the comprehensive evaluation of the degree of soil contamination. Environmental Geochemistry and Health, 40, 2395-2420.

Krzaklewski, W., Barszcz, J., Małek, S., Kozioł, K., \& Pietrzykowski, M. (2004). Contamination of forest soils in the vicinity of the sedimentation pond after zinc and lead ore flotation (in the region of Olkusz, southern Poland). Water, Air, and Soil pollution, 159(1), 151-164.

Labaz, B., Kabala, C., \& Waroszewski, J. (2019). Ambient geochemical baselines for trace elements in ChernozemsApproximation of geochemical soil transformation in an agricultural area. Environmental Monitoring and Assessment, 191, 19.

Li, L., Wu, H., van Gestel, C. A. M., Peijnenburg, W. J. G. M., \& Allen, H. E. (2014). Soil acidification increases metal extractability and bioavailability in old orchard soils of Northeast Jiaodong Peninsula in China. Environmental Pollution, 188, 144-152. 
Loska, K., Wiechuła, D., Barska, K., Cebula, E., \& Chojnecka, A. (2003). Assessment of arsenic enrichment of cultivated soils in southern Poland. Polish Journal of Environmental Studies, 12(2), 187-192.

Loska, K., Wiechuła, D., \& Korus, I. (2004). Metal contamination of farming soils affected by industry. Environment International, 30, 159-165.

MacDonald, D. D., Ingersoll, C. G., \& Berger, T. A. (2000). Development and evaluation of consensus-based sediment quality guidelines for freshwater ecosystems. Archives of Environmental Contamination and Toxicology, 39, 20-31.

Mazurek, R., Kowalska, J., Gąsiorek, M., Zadrożny, P., Józefowska, A., Zaleski, T., et al. (2017). Assessment of heavy metals contamination in surface layers of Roztocze National Park forest soils (SE Poland) by indices of pollution. Chemosphere, 168, 839-850.

Mazurek, R., Kowalska, J. B., Gąsiorek, M., \& Zadrożny, P. (2019). Pollution indices as comprehensive tool for evaluation of the accumulation and provenance of potentially harmful elements in soils in Ojców National Park. Journal of Geochemical Exploration, 201, 13-30.

Pająk, M., Błońska, E., Szostak, M., Gąsiorek, M., Pietrzykowski, M., Urban, O., et al. (2018). Restoration of vegetation in relation to soil properties of spoil heap heavily contaminated with heavy metals. Water, Air, and Soil pollution, 229, 392.

Peng, H., Chen, Y., Weng, L., Ma, J., Ma, Y., Li, Y., et al. (2019). Comparisons of heavy metal input inventory in agricultural soils in North and South China: A review. Science of the Total Environment, 660, 776-786.

Piekut, A., Baranowska, R., Marchwińska-Wyrwał, E., Ćwielạg-Drabek, M., Hajok, I., Dziubanek, G., et al. (2018). Is the soil quality monitoring an effective tool in consumers' protection of agricultural crops from cadmium soil contamination? A case of the Silesia region (Poland). Environmental Monitoring and Assessment, 190, 25.

PN-ISO 10381-4:2007. Soil quality-Sampling: Part 4-Principles for the treatment of natural, near-natural and cultivated areas (in Polish).

PN-ISO 10390:1997. Soil quality-Determination of $p H$ (in Polish).

PN-EN ISO 11885:2009. Water quality-Determination of selected elements by inductively coupled plasma optical emission spectrometry (ICP-OES) (in Polish).

PN-ISO 14235:2003. Soil quality-Determination of organic carbon by sulfochromic oxidation (in Polish).

PN-EN ISO 17294-1:2007. Water quality-Use of inductively induced plasma mass spectrometry (ICP-MS): Part 1General guidelines (in Polish).

PN-EN ISO 17294-2:2006. Water quality-Use of inductively induced plasma mass spectrometry (ICP-MS): Part 2Determination of 62 elements (in Polish).

Postawa, A., \& Motyka, J. (2019). Selected trace elements and metals in groundwater within Permian sediments near Olkusz ( $\mathrm{Zn}-\mathrm{Pb}$ ore mining region, S Poland). Environmental Science and Pollution Research, 26, 34-43.

Potysz, A., Kierczak, J., Pietranik, A., \& Kądziołka, K. (2018). Mineralogical, geochemical, and leaching study of historical $\mathrm{Cu}$-slags issued from processing of the Zechstein formation (Old Copper Basin, south-western Poland). Applied Geochemistry, 98, 22-35.
Pratush, A., Kumar, A., \& Hu, Z. (2018). Adverse effect of heavy metals ( $\mathrm{As}, \mathrm{Pb}, \mathrm{Hg}$, and $\mathrm{Cr}$ ) on health and their bioremediation strategies: a review. International Microbiology, 21, 97-106.

Pueyo, M., López-Sánchez, J. F., \& Rauret, G. (2004). Assessment of $\mathrm{CaCl}_{2}, \mathrm{NaNO}_{3}$ and $\mathrm{NH}_{4} \mathrm{NO}_{3}$ extraction procedures for the study of $\mathrm{Cd}, \mathrm{Cu}, \mathrm{Pb}$ and $\mathrm{Zn}$ extractability in contaminated soils. Analytica Chimica Acta, 504, 217-226.

Qui, H. (2010). Studies on the potential ecological risk and homology correlation of heavy metal in the surface soil. Journal of Agricultural Science, 2(2), 194-201.

Rafacz, S. D. (2019). Healthy eating: approaching the selection, preparation, and consumption of healthy food as choice behavior. Perspectives on Behavior Science. https://doi. org/10.1007/s40614-018-00190-y.

Rauret, G. (1998). Extraction procedures for the determination of heavy metals in contaminated soil and sediments. Talanta, 46(3), 449-455.

RMŚ. (2016). Regulation of the Minister of Environment of 1 September 2016 on how to conduct pollution assessment the surface of the earth (OJ 2016, item 1395) (in Polish).

Rudnick, R. L., \& Gao, S. (2014). Composition of the continental crust. Treatise on Geochemistry (Second Edition), 4, $1-51$.

Satapathy, S., \& Panda, C. R. (2018). Source identification, environmental risk assessment and human health risks associated with toxic elements present in a coastal industrial environment, India. Environmental Geochemistry and Health, 40, 2243-2257.

Shaheen, S. M., \& Rinklebe, J. (2014). Geochemical fractions of chromium, copper, and zinc and their vertical distribution in floodplain soil profiles along the Central Elbe. Geoderma, 228-229, 152-159.

Shi, T., Ma, J., Wu, X., Ju, T., Lin, X., Zhang, Y., et al. (2018). Inventories of heavy metal inputs and outputs to and from agricultural soils: A review. Ecotoxicology and Environmental Safety, 164, 118-124.

Smreczak, B., Siebielec, G., Ukalska-Jaruga, A., \& Klimkowicz-Pawlas, A. (2018). Evaluation of the content of cadmium, zinc, lead and benzo(a)pyrene in agricultural soils20 years of chemical monitoring of arable soils in Poland. In: J. Jadczyszyn, B. Smreczak (Eds.), State of threats for the soil quality in Poland. Studies and reports of the Institute for the Cultivation of Fertilization and Soil Science-National Research Institute in Puławy IUNG-PIB, 58(12), (pp. 81-95). (in Polish).

Štrbac, S., Grubin, M. K., \& Vasić, N. (2017). Importance of background values in assessing the impact of heavy metals in river ecosystems: case study of Tisza River, Serbia. Environmental Geochemistry and Health, 40(4), 1247-1263.

Šukalić, A., Ahmetović, N., Mačkić, S., Leto, A., Džubur, A., \& Antunović, B. (2018). Human health risk assessment of heavy metals from the agricultural soil in South Herzegovina. Agriculturae Conspectus Scientificus, 83(1), 45-50.

Szczepańska, J., \& Twardowska, I. (1999). Distribution and environmental impact of coal-mining wastes in Upper Silesia, Poland. Environmental Geology, 38(3), 249-258.

USEPA. (1989). Risk assessment guidance for superfund, Vol. 1: Human health evaluation manual, Part A, interim final. 
Office of Emergency and Remedial Response. USEPA, Washington, DC, USA.

USEPA. (1991). Role of the baseline risk assessment in superfund remedy selection decisions. OSWER Directive 9355.0-30, Office of Solid Waste and Emergency Response, Washington, DC, USA.

USEPA. (1998). Method 6020B: Inductively coupled plasmamass spectrometry. Revision 2. USEPA, Washington, DC, USA.

USEPA. (2001). Risk assessment guidance for superfund, Vol. 3: Part A, Process for conducting probabilistic risk assessment. Office of Emergency and Remedial Response, USEPA, Washington, DC, USA.

USEPA. (2002). Supplemental guidance for developing soil screening levels for superfund sites. Office of Emergency and Remedial Response. USEPA, Washington, DC, USA, OSWER 9355, 4-24.

USEPA. (2004). Risk assessment guidance for superfund, Vol. 1: Human health evaluation manual (Part E, Supplemental guidance for dermal risk assessment), Final. Office of Superfund Remediation and Technology Innovation. USEPA, Washington, DC, USA.

USEPA. (2008). Child-specific Exposure Factors Handbook. National Center for Environmental Assessment Office of Research and Development. Washington, DC; EPA/600/R06/096F.

USEPA. (2009). Risk assessment guidance for superfund volume I: Human health evaluation manual (part f, supplemental guidance for inhalation risk assessment) final. Office of Superfund Remediation and Technology Innovation, OSWER Directive 9285,7-82, EPA-540-R-070002, US Environmental Protection Agency, Washington, DC, USA.

USEPA. (2011). Exposure factors handbook: 2011 edition. National Center for Environmental Assessment, Washington, DC; EPA/600/R-09/052F.

USEPA. (2014). Human health evaluation manual, supplemental guidance: Update of standard default exposure factors. Office of Solid Waste and Emergency Response, US Environmental Protection Agency, Washington, DC.

USEPA. (2018). Assessing dermal exposure from soil, Region 3. Technical guidance manual, risk assessment. https:// www.epa.gov/risk/assessing-dermal-exposure-soil. Accessed 18 Mar 2019.

USEPA. (2019). Regional screening level (RSL) summary table $(T R=1 E-06, H Q=1)$, April 2019. US Environmental Protection Agency, Washington, DC, USA.
Wadhwa, S. H., Kazi, T. G., Afridi, H. I., \& Naeemullah, F. N. T. (2015). Interaction between carcinogenic and anti-carcinogenic trace elements in the scalp hair samples of different types of Pakistani female cancer patients. Clinica Chimica Acta, 439, 178-184.

Wan, M., Hu, W., Qu, M., Tiam, K., Zhang, H., Wang, Y., et al. (2019). Application of arc emission spectrometry and portable X-ray fluorescence spectrometry to rapid risk assessment of heavy metals in agricultural soils. Ecological Indicators, 101, 583-594.

Wang, P., Li, Z., Liu, J., Bi, X., Ning, Y., Yang, S., et al. (2019). Apportionment of sources of heavy metals to agricultural soils using isotope fingerprints and multivariate statistical analyses. Environmental Pollution, 249, 208-216.

Waroszewski, J., Sprafke, T., Kabała, C., Kobierski, M., Kierczak, J., Musztyfaga, E., et al. (2019). Tracking textural, mineralogical and geochemical signatures in soils developed from basalt-derived materials covered with loess sediments (SW Poland). Geoderma, 337, 983-997.

Wcisło, E., Bronder, J., Bubak, A., Rodríguez-Valdés, E., \& Gallego, J. L. R. (2016). Human health risk assessment in restoring safe and productive use of abandoned contaminated sites. Environment International, 94, 436-448.

Weissmanová, H. D., \& Pavlovský, J. (2017). Indices of soil contamination by heavy metals-Methodology of calculation for pollution assessment (minireview). Environmental Monitoring and Assessment, 189(16), 616.

Wieczorek, J., Baran, A., Urbański, K., Mazurek, K., \& Klimkowicz-Pawlas, A. (2018). Assessment of the pollution and ecological risk of lead and cadmium in soils. Environmental Geochemistry and Health, 40(6), 2325-2342.

Zhang, M.-K., Liu, Z.-Y., \& Wang, H. (2010). Use of single extraction methods to predict bioavailability of heavy metals in polluted soils to rice. Communications in Soil Science and Plant Analysis, 41(7), 820-831.

Zhuang, P., Zou, B., Li, N. Y., \& Li, Z. A. (2009). Heavy metal contamination in soils and food crops around Dabaoshan mine in Guangdong, China: Implication for human health. Environmental Geochemistry and Health, 31, 707-715.

Publisher's Note Springer Nature remains neutral with regard to jurisdictional claims in published maps and institutional affiliations. 